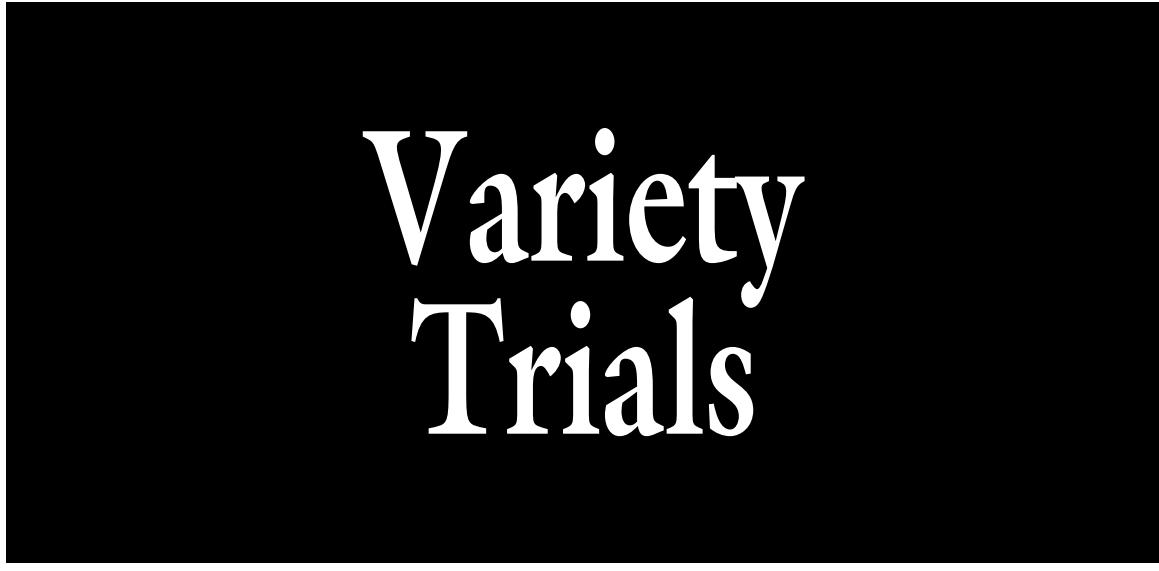

\section{Yield, Quality, and Storage Characteristics of Onion Cultivars in the Columbia Basin of Washington in 2012-14}

\author{
Carrie H. Wohleb ${ }^{1,3}$ and Timothy D. Waters ${ }^{2}$
}

Additional Index words. Allium cepa, dry bulb onion, variety trial, bulb size, market grade, bolting, single centered, neck rot, bacterial rot, internal dry scale

Summary. An onion (Allium cepa) cultivar trial is conducted in the Columbia Basin of Washington every year. The trial helps onion growers, packers, processors, and seed companies compare cultivars and identify those most suited to their operations. This report evaluates 54 onion cultivars that were in the trials 2 years or more from 2012 to 2014. Marketable yields of cultivars averaged 764 to $1314 \mathrm{cwt} /$ acre. 'TTA-747', 'Scout', 'SV6672NW', 'Montero', 'XP07716000', and 'SV4058NV' had the highest yields. All cultivars produced more jumbo-sized ( 3 to 4 inches) bulbs compared with any other size category, but those with the largest percentages of jumbo bulbs were Utrero, Gunnison, and Sedona. 'Scorpion', 'Ruby Ring', and 'Purple Haze' had the largest percentages of medium (2.25 to 3 inches) bulbs, and 'Montero' and 'Ovation' had the largest combined percentages of jumbo and colossal ( $>4$ inches) bulbs. Cultivar differences were evident in the 2012 and 2014 trials when many of the onions flowered (bolted). Cultivars averaged 0.0 to 15.5 bolted onions per plot when 2012 and 2014 results were combined. 'Trekker', 'Highlander', 'Trailblazer', 'Ruby Ring', 'NUN8003ON', and 'Milestone' had the fewest bolted onions. Cultivar differences were also apparent when several aspects of bulb quality were evaluated after 4 months in storage. 'Utrero', 'Trekker', 'NUN7202ON', and 'Tamara' had the most uniformly shaped bulbs. Bulbs of 'Crockett', 'Legend', and 'Utrero' had the most complete skins. 'Crockett', 'Talon', 'Utrero', 'Legend', 'Gunnison', and 'Tamara' had the firmest bulbs. Only 14 of 54 cultivars averaged more than $74 \%$ functionally single-centered bulbs. 'NUN7202ON', 'Arcero', 'Joaquin', and 'Utrero' had the largest percentages of bulbs with single centers or small multiple centers. There were more rots caused by bacteria (Enterobacter sp.) in bulbs produced in the 2014 trial than in 2012 and 2013 , probably due to a high incidence of internal dry scale in 2014. Incidence of bacterial rot in cultivars was not significantly different in 2014, but there were some cultivar differences in 2012 and 2013. Incidence of fungal neck rot (caused by Botrytis sp.) in these trials was low and there were no significant cultivar differences. The results of these trials demonstrate that many new and advanced experimental cultivars have attributes that could make them a good choice for onion growers in the Columbia Basin. the late summer and fall. In 2013, there were 11.6 million cwt of summer storage onions harvested from 20,000 acres in Washington, which were valued at \$141 million (USDA, 2014a). Most onion farms in Washington are located within the Columbia Basin Project, a U.S. Bureau of Reclamation irrigation project serving 671 thousand acres in a semiarid region in east central Washington (U.S. Bureau of Reclamation, 2015). Onions are also produced on farmland adjacent to the project, including farms across the border in northeastern Oregon. The entire region is referred to as the Columbia Basin Plateau or the Columbia Basin. Most of the onions grown in the $\mathrm{Co}^{-}$ lumbia Basin are long-day cultivars, mainly globe $\times$ sweet Spanish hybrids, and $\approx 85 \%$ are yellow cultivars, with $10 \%$ red, and $5 \%$ white cultivars (Pelter and Sorensen, 2003). Almost 70\% of the onions grown in Washington are intended for the fresh market (domestic and export), with the remainder used for processing (precut rings, slabs, slices, petal cuts, dices, etc.) (USDA, 2014b).

Many different onion cultivars are grown commercially in the Columbia Basin, but the cultivar makeup changes regularly as growers, packers, and processors learn about improved cultivars being introduced by seed companies. Since 1984, Washington State University (WSU) personnel have organized an onion cultivar trial in the Columbia Basin to provide information about the performance of available cultivars. A different commercial onion grower hosts the trial each year and provides considerable in-kind support by maintaining the onions from seeding to harvest and through 4 months of storage. Onion seed companies submit entries and provide funding for the trial on a per-entry basis. Most of the seed companies operating in the region participate. There are typically 50-60 entries each year, with many standard cultivars included for comparison with new and advanced experimental cultivars. A field day event is held at the trial location every August so onion
W ashington's onion growers produce $\approx 20 \%$ of the dry bulb onion crop in the United States each year [U.S. Department of Agriculture (USDA), 2014a]. Most of these are summer storage onions planted in the spring and harvested in

\begin{tabular}{llll}
\hline $\begin{array}{l}\text { Units } \\
\text { To convert U.S. to SI, } \\
\text { multiply by }\end{array}$ & U.S. unit & SI unit & $\begin{array}{l}\text { To convert SI to U.S., } \\
\text { multiply by }\end{array}$ \\
\hline 45.3592 & $\mathrm{cwt}$ & $\mathrm{kg}$ & 0.0220 \\
112.0851 & $\mathrm{cwt} / \mathrm{acre}$ & $\mathrm{kg} \cdot \mathrm{ha}^{-1}$ & 0.0089 \\
0.3048 & $\mathrm{ft}$ & $\mathrm{m}$ & 3.2808 \\
2.54 & inch $(\mathrm{es})$ & $\mathrm{cm}$ & 0.3937 \\
$\left({ }^{\circ} \mathrm{F}-32\right) \div 1.8$ & ${ }^{\circ} \mathrm{F}$ & ${ }^{\circ} \mathrm{C}$ & $\left({ }^{\circ} \mathrm{C} \times 1.8\right)+32$
\end{tabular}

Horflechnology · April 2016 26(2) 
stakeholders can view the cultivars while they are growing. The event is attended by 100-150 people each year. Harvest and storage evaluation days are also attended by onion stakeholders who use those opportunities to examine and compare the cultivars more closely. Summarized results from the field and storage evaluations are provided in two reports each year that are sent to more than 400 onion stakeholders. The reports are also archived and available online (WSU, 2015).

The WSU Onion Cultivar Trial helps seed companies to determine if their new and advanced experimental cultivars are suitable for production in the Columbia Basin, which is a unique area for growing onions especially with regard to climate and daylength. To produce an acceptable crop, cultivated onions must be well adapted to the temperatures and photoperiods of the locations they are grown (Brewster, 2008). The trial also allows seed companies to demonstrate the attributes of their onion cultivars and promote them to growers.

Onion growers in the Columbia Basin use the WSU Onion Cultivar Trial to identify cultivars with qualities that are most suited to their needs and market opportunities. Generally, they look for cultivars with high yield potential, and those that produce a large proportion of marketable bulbs in the size categories that pay a premium or are most saleable. Attractive color and shape are also important. Since onions in this region are usually stored, they also look for cultivars that have uniformly shaped bulbs, with complete skins, that stay firm, and do not sprout in storage. Cultivars that are less susceptible to storage rots are also desired. Commercial onion growers have different needs depending on how the crop

\footnotetext{
${ }^{1}$ Associate Professor, Washington State University, Grant-Adams Extension, 1525 E. Wheeler Road, Moses Lake, WA 98837

${ }^{2}$ Associate Professor, Washington State University, Franklin-Benton Extension, 404 W. Clark Avenue, Pasco, WA 99301

We thank the growers that hosted the WSU Onion Cultivar Trials, in 2012, 2013, and 2014 including Larry and Kerrick Bauman and Kevin Kudsk of L \& L Ag Production, LLC; Brent Hartley, Taryn Hartley, and Troy Hartley of Hartley Farms, LLC; and Wally Huppert of Carr Farms, LLC and also thank Marcel Wanders, Deron Beck, and Jordan Carey of Seminis Vegetable Seeds, Inc. for planting the trials each season. A special thanks to Lindsey du Toit for her guidance and help in rating storage rot diseases during the poststorage evaluations.

${ }^{3}$ Corresponding author. E-mail: cwohleb@wsu.edu.
}

will be used. For instance, growers that supply onions for processing into onion rings prefer cultivars that produce large bulbs with single centers (i.e., have a single growing point), because small onions and those with large multiple centers result in fewer usable rings.

The WSU Onion Cultivar Trial is conducted in a different growercooperator field each year, so cultivars entered multiple years may be evaluated using a range of production practices. Irrigation system is one of the most important variables. Over the years, irrigation for the trial has been provided by center pivot, drip tape, and before 2005 by furrow irrigation. The use of furrow irrigation in the Columbia Basin has declined sharply since the 1980s, and it is estimated that $70 \%$ of the onions grown in the region today are irrigated using center-pivot systems. Drip irrigation has also gained popularity, and $\approx 25 \%$ of the onion crop is irrigated using this method. The irrigation system used by growers can influence their choice of cultivar. For instance, cultivars with an upright growth habit are sometimes promoted by seed companies for use under center-pivot irrigation, because cultivars with a spreading or open-neck growth habit are thought to be more susceptible to soft rots caused by bacteria (Dickeya chrysanthemi and Pectobacterium carotovorum). Overhead sprinkler irrigation can result in a favorable environment for bacterial soft rots (Teviotdale et al., 1989), but we are not aware of studies that have demonstrated differences in cultivar susceptibility to soft rots based on growth habit.

Planting configuration i.e., bed width and plant spacing, is another important variable for onion production systems in the Columbia Basin. Most onions are seeded 3 to 4 inches apart in multiple rows on raised beds, but bed width and the number of rows per bed vary depending on the farm or field. Typically, two double rows are planted $\approx 12$ inches apart on $34,38,40$, or 44 inches of bed width. Onion growers use different planting configurations to manipulate onion bulb size. Plant population is understood to be closely related to onion bulb size distribution, and sometimes to total marketable onion yield (Brewster, 2008; Shock et al., 2004). A shift to larger bulb size is favored by low plant population and less plant competition. Conversely, higher plant population and more competition results in smaller bulb size and sometimes higher total marketable yield.

This report compares 54 onion cultivars that were entered in the WSU Onion Cultivar Trials for 2 years or more from 2012 to 2014 . This includes eight advanced experimental cultivars. Yield, bulb size distribution, and defects are evaluated for each cultivar, as are several aspects of bulb quality and storability.

\section{Materials and methods}

The onion cultivar trials in 2012, 2013, and 2014 were planted in March or April using pelleted seeds and a precision belt planter (Stanhay Webb, Grantham, England, UK) owned by Seminis Vegetable Seeds (Parma, ID) and operated by their field research staff. Each year, seeds of each cultivar were planted in replicated plots arranged in a randomized complete block design with three replications. Each plot was $30 \mathrm{ft}$ long with two double rows of seeded onions, and 5-ft-long alleys separating the ends of adjacent plots. All trials were seeded at an in-row spacing of 4 inches, but bed widths varied each year. Field preparation before seeding and all management after seeding and up to harvest was done by the growercooperator. Each used standard practices for ground preparation, fertility, and pest management. In Sept. 2012 and 2014, the number of bolted onions in each plot was recorded. Bolting was not evaluated in 2013. Each year, the onions were undercut and left to dry in the field a few days before harvest. Harvest was in late September or early October and was just before harvest of the grower's crop surrounding the trial. Bulbs from a 5 -ft section of each plot were topped, harvested, and sized by hand. Onions from the harvested sections of each plot were sorted into culls and marketable bulbs, and then weighed, and total yield and marketable yield were recorded. Culls included double bulbs, split bulbs, rotten bulbs, and onions that had bolted. Bulbs were sized, based on diameter, and the number of bulbs in each of four size classes was recorded. Size classes were prepack $(<2.25$ inches $)$, medium $(2.25$ to 3 inches), jumbo (3 to 4 inches), and colossal ( $>4$ inches). The number of cull bulbs was also recorded. The total 
Table 1. Descriptions of the 54 onion cultivars evaluated in the Washington State University Onion Cultivar Trials in 2012, 2013, and 2014.

\begin{tabular}{|c|c|c|c|c|c|c|}
\hline Cultivar & Seed company ${ }^{\mathrm{z}}$ & Color & Daylength ${ }^{\mathrm{y}}$ & Maturity $^{\mathrm{x}}(\mathrm{d})$ & Storage $^{\mathrm{w}}$ (mo.) & Yr evaluated \\
\hline Advantage & Crookham & Yellow & Long & 130 & $4-6$ & 2012,2013 \\
\hline Anillo & Nunhems & Yellow & Long & $116-118$ & $4-6$ & $2012,2013,2014$ \\
\hline Arcero & Nunhems & Yellow & Long & $118-120$ & $4-6$ & $2012,2013,2014$ \\
\hline Bello Blanco & Sakata & White & Long & & & 2012,2013 \\
\hline Belmar & Seminis & Yellow & Long & 118 & 6 & $2012,2013,2014$ \\
\hline Brundage & Crookham & White & Long & 125 & $4-6$ & 2013,2014 \\
\hline Centerstone & American Takii & Yellow & Long & & & $2012,2013,2014$ \\
\hline Cometa & Nunhems & White & Long & $112-115$ & $4-6$ & $2012,2013,2014$ \\
\hline Countach & Nunhems & Red & Long & $119-121$ & $4-6$ & 2012,2014 \\
\hline Crockett & Bejo & Yellow & Long & 118 & 8 & $2012,2013,2014$ \\
\hline Cruiser & Hazera & Yellow & Long & 115 & & $2012,2013,2014$ \\
\hline Delgado & Bejo & Yellow & Long & 115 & 7 & $2012,2013,2014$ \\
\hline Gunnison & Bejo & Yellow & Long & 110 & 7 & 2012,2013 \\
\hline Highlander & American Takii & Yellow & Long & $85-90$ & & 2013,2014 \\
\hline Joaquin & Nunhems & Yellow & Long & $130-135$ & $4-6$ & $2012,2013,2014$ \\
\hline Legend & Bejo & Yellow & Long & 118 & 6 & $2012,2013,2014$ \\
\hline Marenge & Nunhems & Red & Long & $118-120$ & $4-6$ & $2012,2013,2014$ \\
\hline Maverick & Hazera & Yellow & Long & 120 & 5 & $2012,2013,2014$ \\
\hline Milestone & American Takii & Yellow & Long & $105-110$ & 6 & $2012,2013,2014$ \\
\hline Montero & Nunhems & Yellow & Long & $105-110$ & $2-4$ & $2012,2013,2014$ \\
\hline Morpheus & Crookham & Yellow & Long & 120 & $4-6$ & $2012,2013,2014$ \\
\hline NUN7202ON (Oloroso) & Nunhems & Yellow & Long & & & 2013,2014 \\
\hline NUN8003ON & Nunhems & White & Long & & & 2013,2014 \\
\hline Ovation & Sakata & Yellow & Int./Long & & & $2012,2013,2014$ \\
\hline Scout & Crookham & Yellow & Int./Long & 100 & $3-4$ & $2012,2013,2014$ \\
\hline Sedona & Bejo & Yellow & Long & 120 & 6 & 2013,2014 \\
\hline SV4058NV & Seminis & White & Long & & & $2012,2013,2014$ \\
\hline SV4643NT & Seminis & Red & Long & & & $2012,2013,2014$ \\
\hline SV6646NW & Seminis & Yellow & Long & & & 2013,2014 \\
\hline SV6672NW & Seminis & Yellow & Long & $116-118$ & & 2013,2014 \\
\hline Swale & Seminis & Yellow & Long & 120 & 6 & $2012,2013,2014$ \\
\hline Talon & Bejo & Yellow & Long & 110 & 7 & $2012,2013,2014$ \\
\hline Tamara & Bejo & Yellow & Long & 112 & 7 & 2012,2013 \\
\hline Trailblazer & American Takii & Yellow & Long & & Long & $2012,2013,2014$ \\
\hline Trekker & American Takii & Yellow & Long & $95-100$ & & $2012,2013,2014$ \\
\hline Trigger & Crookham & Yellow & Long & 135 & $6+$ & 2012,2014 \\
\hline TTA-747 & American Takii & Yellow & Long & $125+$ & & 2012,2013 \\
\hline Utrero & Nunhems & Yellow & Long & & & 2013,2014 \\
\hline Valero & Nunhems & Yellow & Long & $112-115$ & $4-6$ & 2013,2014 \\
\hline Vaquero & Nunhems & Yellow & Long & $118-120$ & $4-6$ & $2012,2013,2014$ \\
\hline Ventura & Hazera & Yellow & Long & 115 & 5.5 & 2012,2013 \\
\hline XP0771600 & Seminis & Yellow & Long & 118 & 6 & 2013,2014 \\
\hline
\end{tabular}

${ }^{\mathrm{z} A m e r i c a n}$ Takii $($ Salinas, CA), Bejo $=$ Bejo Seeds $($ Oceano, CA), Crookham $=$ Crookham Co. $($ Caldwell, ID), Hazera $=$ Hazera Seeds $($ Tuscon, AZ), Nunhems $=$ Nunhems USA (Brooks, OR), Sakata = Sakata Seed America (Messilla, NM), Seminis = Seminis Vegetable Seeds (Parma, ID).

"Relative photoperiod or daylength needed to induce bulb development, typically described as "long," "intermediate" (Int.), or "short."

${ }^{x}$ Number of days it usually takes to grow from planting to maturity as reported by seed companies in promotional materials.

${ }^{\mathrm{w}}$ Maximum period of storage recommended in promotional materials provided by seed companies. 
Table 2. Average total marketable yield and bulb size distribution for onions evaluated in the Washington State University Onion Cultivar Trials in 2012, 2013, and 2014.

\begin{tabular}{|c|c|c|c|c|c|c|c|}
\hline \multirow[b]{2}{*}{$\underline{Y r}$} & \multicolumn{6}{|c|}{ Marketable yield $^{\mathrm{z}}$} & \multirow[b]{2}{*}{ Bolters (no.) } \\
\hline & Total (cwt/acre) ${ }^{\mathrm{y}}$ & Prepack $(\%)^{x}$ & Medium (\%) & Jumbo (\%) & Colossal (\%) & Culls (\%) & \\
\hline 2012 & 1134 & 2.0 & 18.3 & 65.6 & 9.4 & 4.7 & 7.9 \\
\hline 2014 & 952 & 2.2 & 24.4 & 66.9 & 2.4 & 4.2 & 3.5 \\
\hline \multicolumn{8}{|l|}{ ANOVA $^{w}$} \\
\hline Year & 0.0001 & 0.0001 & 0.0001 & 0.0001 & 0.0001 & 0.0001 & 0.0001 \\
\hline
\end{tabular}

${ }^{\mathrm{z}}$ Prepack $=<2.25$ inches, medium $=2.25$ to 3 inches, jumbo $=3$ to 4 inches, colossal $=>4$ inches, culls $=$ double or split bulbs, rotten bulbs, and bulbs with seed stalks; 1 inch $=2.54 \mathrm{~cm}$.

${ }^{\mathrm{y}} 1 \mathrm{cwt} /$ acre $=112.085 \mathrm{lkg} \cdot \mathrm{ha}^{-1}$.

'Percent of the total bulb count.

wAnalysis of variance for the effects of year, cultivar, and year $\times$ cultivar; Ns $=$ not significant at $P \leq 0.01$.
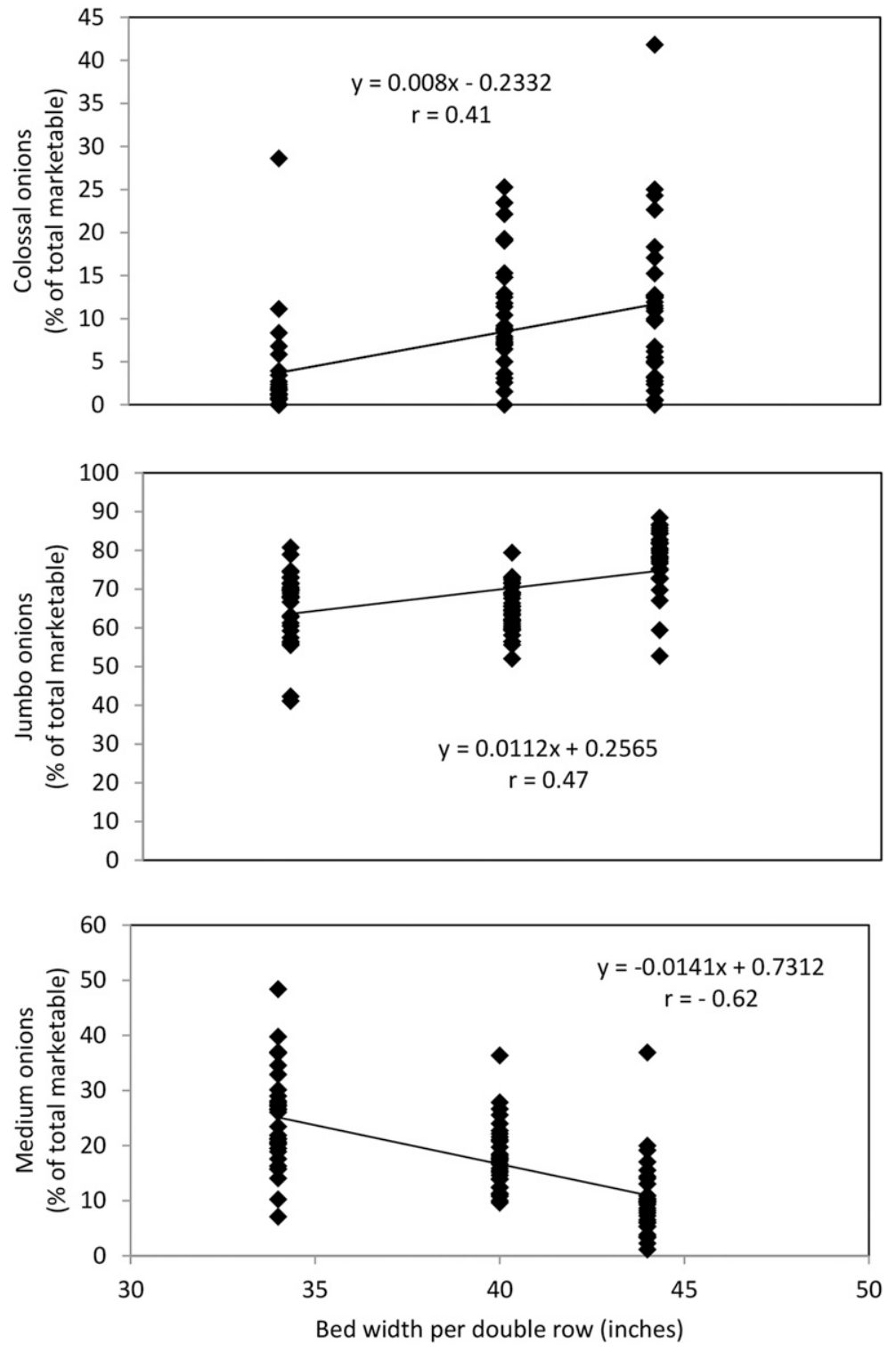

Fig. 1. Correlations between the percentage of the marketable onion bulb yield that were medium (2.25 to 3 inches), jumbo ( 3 to 4 inches), or colossal ( $>4$ inches) size, and the width of beds used to plant double rows of onions. Each data point represents a cultivar averaged across three replications. Only the 31 cultivars that were included in all of the Washington State University Onion Cultivar Trials from 2012 to 2014 are included in this analysis; 1 inch $=2.54 \mathrm{~cm}$. bulb count was used to calculate the percentage of bulbs in each size category. Harvested bulbs were bagged and then placed in bins inside a commercial bulk onion storage facility. Temperature and humidity were managed by the commercial storage operators following standard industry practices. The onions were kept in storage until February, when 50 bulbs per plot were evaluated. The bulbs were rated on a scale of 1 to 5 for firmness ( $1=$ soft bulbs, $5=$ very hard bulbs), skin retention ( $1=75 \%$ or more of the bulb is bald, $2=50 \%$ to $75 \%$ of the bulb is bald, 3 = partial balding but more than $50 \%$ of the skin is present, 4 = complete skin but with some cracks, 5 = complete skin and no cracks), and uniformity of shape ( $1=$ extremely variable shapes, $5=$ highly uniform shape). Each onion was cut in half (longitudinally) and the number of sprouted bulbs was recorded, and then cut again (latitudinally) to determine the number of bulbs with single centers or small multiple centers not exceeding 1 inch in diameter. Onion bulbs with single centers or small multiple centers are said to be "functionally" single centered (Shock et al., 2005). The numbers of bulbs with bacterial bulb rot and fungal neck rot were also recorded.

The 2012 trial was hosted by L \& L Ag. Production in a commercial onion field near Connell, WA (lat. $46^{\circ} 43^{\prime} 32.57^{\prime \prime} \mathrm{N}$, long. $118^{\circ} 58^{\prime} 3.32$ "W) on a Warden silt loam soil. It included 53 cultivars submitted by eight seed companies. The trial was seeded on 3 Apr. 2012 in raised 40 -inch beds with two double rows per bed. The field was irrigated using drip tape. The plants were undercut on 26 Sept. 2012 and harvested on 3 Oct. 2012. Onion bulbs from the trial were 
Table 3. Total marketable yield, bulb size distribution, and culls for each onion cultivar evaluated in the Washington State University Onion Cultivar Trials from 2012 to 2014. Cultivars are presented in order from the largest to the smallest total marketable yield.

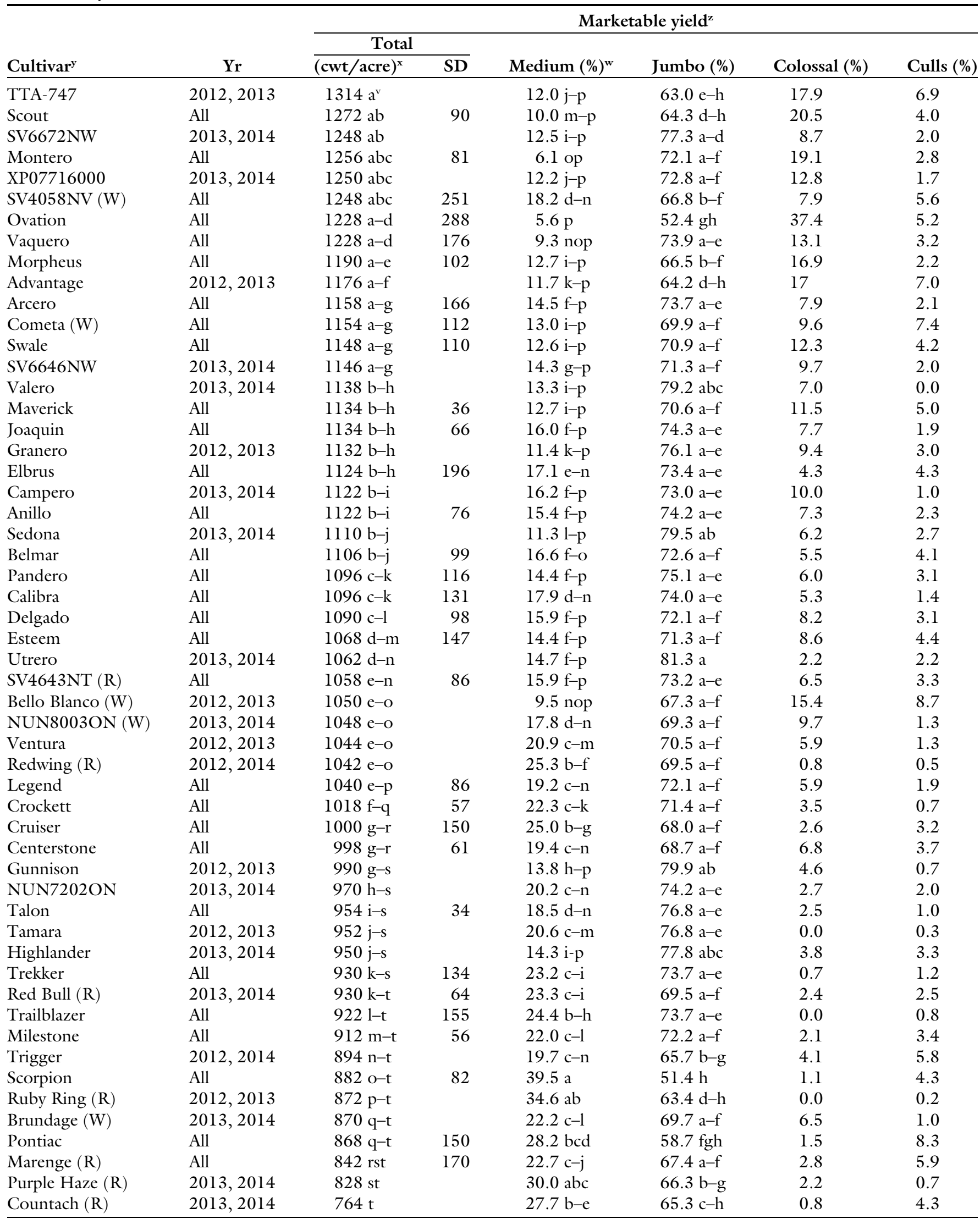


Table 3. (Continued) Total marketable yield, bulb size distribution, and culls for each onion cultivar evaluated in the Washington State University Onion Cultivar Trials from 2012 to 2014 . Cultivars are presented in order from the largest to the smallest total marketable yield.

\begin{tabular}{|c|c|c|c|c|c|c|c|}
\hline \multirow[b]{3}{*}{ Cultivar $^{\mathrm{y}}$} & \multirow[b]{3}{*}{ Yr } & \multicolumn{6}{|c|}{ Marketable yield $^{\mathrm{z}}$} \\
\hline & & \multicolumn{2}{|c|}{ Total } & \multirow[b]{2}{*}{ Medium (\%) ${ }^{w}$} & \multirow[b]{2}{*}{ Jumbo (\%) } & \multirow[b]{2}{*}{ Colossal (\%) } & \multirow[b]{2}{*}{ Culls (\%) } \\
\hline & & $(\mathrm{cwt} / \mathrm{acre})^{\mathrm{x}}$ & SD & & & & \\
\hline \multicolumn{8}{|l|}{ ANOVA } \\
\hline Year & & 0.0001 & & 0.0001 & 0.0001 & 0.0001 & 0.0001 \\
\hline Cultivar & & 0.0001 & & 0.0001 & 0.0007 & 0.0001 & NS \\
\hline
\end{tabular}

ANOVA $=$ analysis of variance.

${ }^{\mathrm{z}}$ Medium $=2.25$ to 3 inches, jumbo $=3$ to 4 inches, collosal $=>4$ inches, culls $=$ double or split bulbs, rotten bulbs, and bulbs with seed stalks at the time of harvest; 1 inch $=$ $2.54 \mathrm{~cm}$.

$\mathrm{y}(\mathrm{R})=$ red cultivar, $(\mathrm{W})=$ white cultivar; cultivars that are not red or white are yellow.

${ }^{\mathrm{x}} \mathrm{l} \mathrm{cwt} / \mathrm{acre}=112.085 \mathrm{l} \mathrm{kg} \cdot \mathrm{ha}^{-1}$.

wercent of the total bulb count.

"Values followed by different letters within a column are significantly different using Fisher's least significant difference test at the $1 \%$ level; Ns $=$ not significant at $P \leq 0.01$.

Table 4. The average percentage of colossal-sized bulbs for each onion cultivar evaluated in the Washington State University Onion Cultivar Trials in 2012, 2013, and 2014. Cultivars are presented in order from the largest to the smallest total marketable yield.

\begin{tabular}{|c|c|c|c|}
\hline \multirow[b]{2}{*}{ Cultivar $^{\mathrm{z}}$} & \multicolumn{3}{|c|}{ Colossal (\% of total count $)^{y}$} \\
\hline & 2012 & 2013 & 2014 \\
\hline TTA-747 & $13.4 c-h^{x}$ & $22.3 \mathrm{~b}-\mathrm{f}$ & \\
\hline Scout & $25.0 \mathrm{bc}$ & $25.3 \mathrm{~b}$ & $11.3 \mathrm{~b}$ \\
\hline SV6672NW & & $16.0 \mathrm{~b}-\mathrm{j}$ & $1.3 \mathrm{~d}$ \\
\hline Montero & $29.3 \mathrm{ab}$ & $24.7 \mathrm{bc}$ & $3.3 \mathrm{~cd}$ \\
\hline XP07716000 & & $23.7 \mathrm{bcd}$ & $2.0 \mathrm{~cd}$ \\
\hline SV4058NV (W) & $9.3 \mathrm{~d}-\mathrm{j}$ & $12.7 \mathrm{~d}-\mathrm{m}$ & $1.7 \mathrm{~cd}$ \\
\hline Ovation & $40.7 \mathrm{a}$ & $42.7 \mathrm{a}$ & $28.7 \mathrm{a}$ \\
\hline Vaquero & $19.2 \mathrm{~b}-\mathrm{e}$ & $18.7 \mathrm{~b}-\mathrm{g}$ & $1.3 \mathrm{~d}$ \\
\hline Morpheus & $19.1 \mathrm{~b}-\mathrm{e}$ & $23.0 \mathrm{~b}-\mathrm{e}$ & $8.7 \mathrm{bc}$ \\
\hline Advantage & $9.4 \mathrm{~d}-\mathrm{j}$ & $24.7 \mathrm{bc}$ & \\
\hline Arcero & $11.3 \mathrm{~d}-\mathrm{j}$ & $10.3 \mathrm{~g}-\mathrm{q}$ & $2.0 \mathrm{~cd}$ \\
\hline Cometa $(\mathrm{W})$ & $15.6 \mathrm{c}-\mathrm{g}$ & $12.0 \mathrm{e}-\mathrm{O}$ & $1.3 \mathrm{~d}$ \\
\hline Swale & $20.2 \mathrm{bcd}$ & $16.0 \mathrm{~b}-\mathrm{j}$ & $0.7 \mathrm{~d}$ \\
\hline SV6646NW & & $15.3 \mathrm{~b}-\mathrm{k}$ & $4.0 \mathrm{~cd}$ \\
\hline Valero & & $13.3 c-1$ & $0.7 \mathrm{~d}$ \\
\hline Maverick & $17.4 \mathrm{~b}-\mathrm{f}$ & $11.3 \mathrm{f}-\mathrm{q}$ & $5.7 \mathrm{bcd}$ \\
\hline Joaquin & 3.0 hij & $17.3 \mathrm{~b}-\mathrm{i}$ & $2.7 \mathrm{~cd}$ \\
\hline Granero & $6.9 \mathrm{f}-\mathrm{j}$ & $12.0 \mathrm{e}-\mathrm{O}$ & \\
\hline Elbrus & $4.7 \mathrm{~g}-\mathrm{j}$ & $7.0 \mathrm{~h}-\mathrm{q}$ & $1.3 \mathrm{~d}$ \\
\hline Campero & & $18.0 \mathrm{~b}-\mathrm{h}$ & $2.0 \mathrm{~cd}$ \\
\hline Anillo & $6.9 \mathrm{f}-\mathrm{j}$ & & $4.0 \mathrm{~cd}$ \\
\hline Sedona & $7.0 \mathrm{~h}-\mathrm{q}$ & & $5.3 \mathrm{bcd}$ \\
\hline Belmar & $5.4 \mathrm{f}-\mathrm{j}$ & $10.0 \mathrm{~g}-\mathrm{q}$ & $1.0 \mathrm{~d}$ \\
\hline Pandero & $12.7 \mathrm{~d}-\mathrm{i}$ & $5.3 \mathrm{j}-\mathrm{q}$ & $0.0 \mathrm{~d}$ \\
\hline Calibra & $88.3 \mathrm{abc}$ & $11.7 \mathrm{e}-\mathrm{p}$ & $0.0 \mathrm{~d}$ \\
\hline Delgado & $9.6 \mathrm{~d}-\mathrm{j}$ & $13.0 \mathrm{~d}-\mathrm{m}$ & $2.0 \mathrm{~cd}$ \\
\hline Esteem & $13.5 \mathrm{c}-\mathrm{h}$ & $12.3 \mathrm{~d}-\mathrm{n}$ & $0.0 \mathrm{~d}$ \\
\hline Utrero & & $3.71-\mathrm{q}$ & $0.7 \mathrm{~d}$ \\
\hline SV4643NT (R) & $6.5 \mathrm{f}-\mathrm{j}$ & $6.3 \mathrm{i}-\mathrm{q}$ & $6.7 \mathrm{bcd}$ \\
\hline Bello Blanco $(W)$ & $13.5 \mathrm{c}-\mathrm{h}$ & $17.3 \mathrm{~b}-\mathrm{i}$ & \\
\hline NUN8003ON (W) & & $18.0 \mathrm{~b}-\mathrm{h}$ & $1.3 \mathrm{~d}$ \\
\hline Ventura & $5.8 \mathrm{f}-\mathrm{j}$ & $11.0 \mathrm{f}-\mathrm{q}$ & \\
\hline Redwing (R) & 1.6 hij & & $0.0 \mathrm{~d}$ \\
\hline Legend & $12.1 \mathrm{~d}-\mathrm{j}$ & $5.0 \mathrm{j}-\mathrm{q}$ & $0.7 \mathrm{~d}$ \\
\hline Crockett & $9.8 \mathrm{~d}-\mathrm{j}$ & $0.7 \mathrm{opq}$ & $0.0 \mathrm{~d}$ \\
\hline
\end{tabular}

(Continued on next page) stored at Target Ag. Production (Othello, WA) until 8 Feb. 2013.

The 2013 trial was located in a field of commercial onions owned and managed by Hartley Produce southeast of Prosser, WA (lat. $46^{\circ} 5^{\prime} 33.75^{\prime \prime} \mathrm{N}$, long. $119^{\circ} 28^{\prime} 17.82^{\prime \prime} \mathrm{W}$ ) on a Ritzville silt loam soil. The trial included $55 \mathrm{cul}-$ tivars submitted by seven seed companies. The trial was planted on 27 Mar. 2013. Raised beds were 44 inches wide and seeded with two double rows per bed. Irrigation was provided by center pivot. The onion plants were undercut on 18 Sept. 2013 and harvested on 20 Sept. 2013. Onion bulbs from the trial were stored in a commercial storage facility adjacent to the field until 6 Feb. 2014.

The 2014 trial was located in an onion field owned and managed by Carr Farms northeast of Pasco, WA (lat. $46^{\circ} 17^{\prime} 13.95^{\prime \prime} \mathrm{N}$, long. $\left.118^{\circ} 52^{\prime} 55.54^{\prime \prime} \mathrm{W}\right)$, on a Kahlotus very fine sandy loam soil. The trial included 54 cultivars submitted by eight seed companies. The trial was seeded on 24 Mar. 2014 in raised 34-inch beds with two double rows. Irrigation was provided by center pivot. The plants were undercut on 8 Sept. 2014 and harvested on 15 Sept. 2014. Onion bulbs were stored at a storage facility operated by Carr Farms in Pasco, WA, until 9 Feb. 2015.

There were 54 onion cultivars entered in the trials for 2 years or more between 2012 and 2014, including 42 yellow, 7 red, and 5 white cultivars (Table 1). Data for individual years were analyzed using analysis of variance (ANOVA) and means were separated using Fisher's least significance difference $(P \leq 0.01)$. Then, data 
Table 4. (Continued) The average percentage of colossal-sized bulbs for each onion cultivar evaluated in the Washington State University Onion Cultivar Trials in 2012, 2013, and 2014. Cultivars are presented in order from the largest to the smallest total marketable yield.

\begin{tabular}{|c|c|c|c|}
\hline \multirow[b]{2}{*}{ Cultivar $^{\mathrm{z}}$} & \multicolumn{3}{|c|}{ Colossal (\% of total count) } \\
\hline & 2012 & 2013 & 2014 \\
\hline Cruiser & $7.5 \mathrm{e}-\mathrm{j}$ & $0.3 \mathrm{pq}$ & $0.0 \mathrm{~d}$ \\
\hline Centerstone & $5.5 \mathrm{f}-\mathrm{j}$ & $12.3 \mathrm{~d}-\mathrm{n}$ & $2.7 \mathrm{~cd}$ \\
\hline Gunnison & 3.3 hij & $6.0 \mathrm{i}-\mathrm{q}$ & \\
\hline NUN7202ON & & $5.3 \mathrm{j}-\mathrm{q}$ & $0.0 \mathrm{~d}$ \\
\hline Talon & $3.6 \mathrm{~g}-\mathrm{j}$ & $3.31-\mathrm{q}$ & $0.7 \mathrm{~d}$ \\
\hline Tamara & $0.0 \mathrm{j}$ & $0.0 \mathrm{q}$ & $0.0 \mathrm{~d}$ \\
\hline Highlander & & $6.0 \mathrm{i}-\mathrm{q}$ & $2.0 \mathrm{~cd}$ \\
\hline Trekker & 1.5 hij & $0.0 \mathrm{q}$ & $0.7 \mathrm{~d}$ \\
\hline Red Bull (R) & $1.1 \mathrm{ij}$ & $5.3 j-q$ & $0.7 \mathrm{~d}$ \\
\hline Trailblazer & $0.0 \mathrm{j}$ & $0.0 \mathrm{q}$ & $0.0 \mathrm{~d}$ \\
\hline Milestone & $1.0 \mathrm{ij}$ & $3.7 \mathrm{l}-\mathrm{q}$ & $1.7 \mathrm{~cd}$ \\
\hline Trigger & $8.2 \mathrm{~d}-\mathrm{j}$ & & $0.0 \mathrm{~d}$ \\
\hline Scorpion & $0.5 \mathrm{ij}$ & $2.71-\mathrm{q}$ & $0.0 \mathrm{~d}$ \\
\hline Ruby Ring (R) & $0.0 \mathrm{j}$ & $0.0 \mathrm{q}$ & \\
\hline Brundage $(\mathrm{W})$ & & $13.0 \mathrm{~d}-\mathrm{m}$ & $0.0 \mathrm{~d}$ \\
\hline Pontiac & $2.2 \mathrm{hij}$ & $1.7 \mathrm{~m}-\mathrm{q}$ & $0.7 \mathrm{~d}$ \\
\hline Marenge (R) & $5.5 \mathrm{f}-\mathrm{j}$ & $2.31-\mathrm{q}$ & $0.7 \mathrm{~d}$ \\
\hline Purple Haze (R) & & $4.3 \mathrm{k}-\mathrm{q}$ & $0.0 \mathrm{~d}$ \\
\hline Countach (R) & & $1.0 \mathrm{n}-\mathrm{q}$ & \\
\hline Grand mean & 9.4 & 10.8 & 2.4 \\
\hline
\end{tabular}

${ }^{\mathrm{z}}(\mathrm{R})=$ red cultivar, $(\mathrm{W})=$ white cultivar; cultivars that are not red or white are yellow.

${ }^{y}$ Collosal $=>4$ inches; 1 inch $=2.54 \mathrm{~cm}$.

'Values followed by different letters within a column are significantly different using Fisher's least significant difference test at the $1 \%$ level.

were combined in a summary across trial years and subjected to ANOVA. Cultivar means for results that showed no significant year $\times$ cultivar interaction were averaged across years and compared using Fisher's least significant difference $(P \leq 0.01)$. Data were analyzed using ARM 9 and ARM ST 8 software from Gylling Data Management (Brookings, SD).

\section{Results and discussion}

Total marketable yield differed between years and between cultivars, but there was no cultivar $x$ year interaction. The yield of marketable onion bulbs was lowest in 2014, averaging $952 \mathrm{cwt} / \mathrm{acre}$. The yields were similar in 2012 and 2013 , averaging $1134 \mathrm{cwt} /$ acre and $1102 \mathrm{cwt} /$ acre, respectively. The proportions of medium, jumbo, and colossal bulbs by total count were also affected by the year and cultivar, and except for colossal-sized bulbs, there were no year $\times$ cultivar interactions for these size categories (Table 2). There was a significant year and year $\times$ cultivar effect for the percentage of prepack bulbs, but no cultivar effect. The 2014 trial averaged the largest percentage of medium-sized bulbs, and the cultivars generally produced fewer colossal-sized bulbs than in 2012 and 2013 (Table 2). Onion bulbs tended to be larger in 2013 , with a larger combined percentage of bulbs in the jumbo and colossal size categories and a smaller percentage of prepack bulbs compared with the 2012 and 2014 trials (Table 2).

These trials were planted on different farms each year and managed by different growers, which allows for some comparison of onion production under different management practices, such as irrigation method and planting configuration. However, it is not easy to differentiate the influences of management vs. environment in these trials. The importance of irrigation system, which was drip tape in 2012 and center pivot in 2013 and 2014, on yield, size distribution, or bulb quality of onion cultivars is not clear. Several years of comparing the results of these onion cultivar trials under different irrigation systems would provide more observations and could help, but controlled studies at one location with both irrigation systems would be better. There were, however, moderate to strong correlations between bed width and the size distribution of onion bulbs in this study (Fig. 1). The percentages of medium, jumbo, and colossal-sized bulbs at three different bed widths were compared in a regression analysis using mean results from the 31 onion cultivars evaluated all 3 years (Fig. 1). Onions were seeded at an in-row spacing of 4 inches all 3 years, but bed widths were 40,44 , and 34 inches per two double rows of onions in 2012, 2013, and 2014, respectively. The regression showed that the percentage of medium bulbs decreased and the percentages of jumbo and colossal bulbs increased as bed width increased. This relationship between plant population and bulb size has often been observed, since onions are less constrained by competition at lower plant populations (Brewster, 2008; Shock et al., 2004).

There were no cultivar $x$ year interactions for total marketable yield, percent medium-sized bulbs, and percent jumbo-sized bulbs, so the results from the 3 years were combined and compared for each cultivar (Table 3 ). Total marketable yield of cultivars averaged across 3 years ranged from 764 to $1314 \mathrm{cwt} /$ acre, and averaged $1058 \mathrm{cwt} /$ acre (Table 3). 'TTA-747' had the highest total marketable yield, which was significantly higher than the yields of 40 other cultivars in the trial (Table 3). The six top-yielding cultivars were TTA-747, Scout, SV6672NW, Montero, XP07716000, and SV4058NV. The advanced experimental cultivar, SV4058NV, was the highest yielding white cultivar, and SV4643NT was the highest yielding red cultivar when the results are averaged across years. The average yield of 'TTA-747' and other cultivars that were only included in the 2012 and 2013 trials (Advantage, Granero, Bello Blanco, Ventura, Gunnison, Tamara, and Ruby Ring) are probably skewed high, because both of those years resulted in higher average yields compared with 2014 . Conversely, the average yield of 'Sedona' and 'Brundage' evaluated in 2013 and 2014, and 'Redwing' evaluated in 2012 and 2014, are probably skewed low. Thirty-six out of 54 cultivars yielded more than $1000 \mathrm{cwt} /$ acre when averaged across years (Table 3). SV4643NT and Redwing were the only red cultivars 
with an average total marketable yield over $1000 \mathrm{cwt} / \mathrm{acre}$. The three lowest yielding cultivars in the trials were red onions, Countach, Purple Haze, and Marenge. Pontiac was the lowest yielding yellow cultivar, and Brundage was the lowest yielding white cultivar when averaged across the years. In general, the cultivars with the highest total marketable yields had a smaller percentage of medium bulbs and a larger percentage of colossal bulbs compared with lower yielding cultivars (Table 3).

All of the cultivars produced a larger percentage of jumbo-sized bulbs compared with any other size category, making up $70.7 \%$ of the bulbs on average (Table 3 ). The cultivars that had the largest proportion of jumbo bulbs when averaged across years were Utrero, Gunnison, and Sedona with values of $81.3 \%$ to $79.9 \%$ (Table 3 ). These percentages were significantly larger than those for eight cultivars, Scorpion, Ovation, Pontiac, TTA-747, Ruby Ring, Advantage, Scout, and Countach, that averaged only $51.4 \%$ to $65.3 \%$ jumbo-sized bulbs. Of these eight cultivars, Scorpion, Pontiac, Ruby Ring, and Countach tended to skew toward smaller-sized bulbs, whereas Ovation, TTA-747, Advantage, and Scout tended to produce larger-sized bulbs. 'Scorpion' had the largest percentage of medium bulbs averaged across years, followed closely by 'Ruby Ring' and 'Purple Haze' (Table 3). Conversely, 'Ovation' produced very large bulbs (Table 4). This cultivar had the largest percentage of colossal bulbs each year with mean values of $40.7 \%, 42.7 \%$, and $28.7 \%$ in 2012, 2013, and 2014, respectively (Table 4). The cultivars that had the largest combined percentages of jumbo and colossal bulbs averaged across years were Montero and Ovation (Table 3). The cultivars Trailblazer, Ruby Ring, and Tamara did not produce any colossal bulbs in the years they were entered in the trials (Table 4).

The standard deviation of total marketable yield for the 31 cultivars that were evaluated in all 3 years is shown in Table 3 . These results indicate that yield of some cultivars was more consistent year to year than others. 'Talon' and 'Maverick' yields were the least variable, whereas 'Ovation', 'SV4058NV', and 'Elbrus' had the most variable yields year to year (Table 3 ).
There was a significant year effect and year $\times$ cultivar interaction on the percentage of culls in the trials (Table 2 ).
Generally, there were higher percentages of culls in the 2012 and 2014 trials than in the 2013 trial. There was no

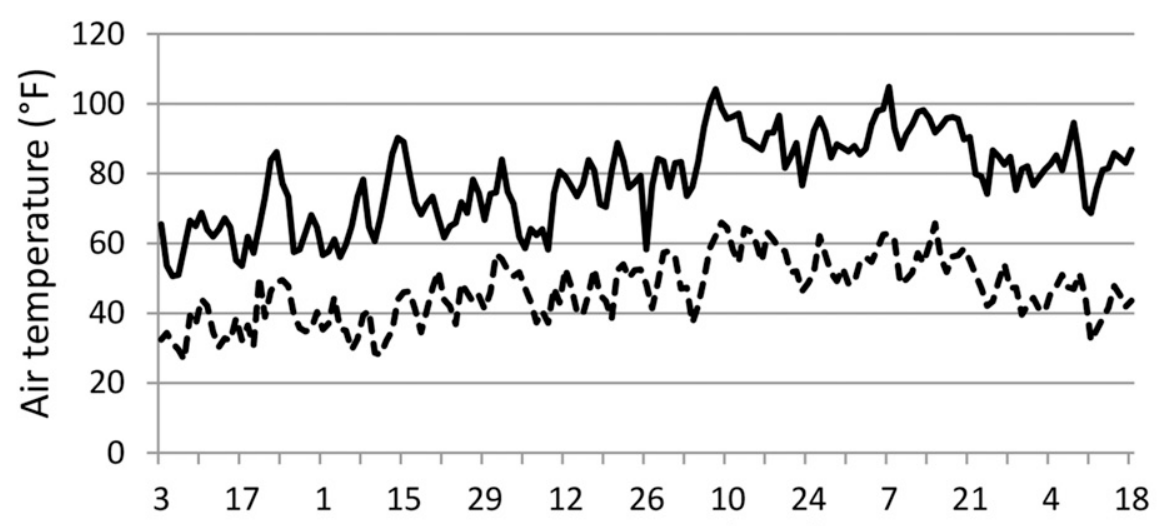

Apr. Apr. May May May June June July July Aug. Aug. Sept. Sept.

Date - 2012

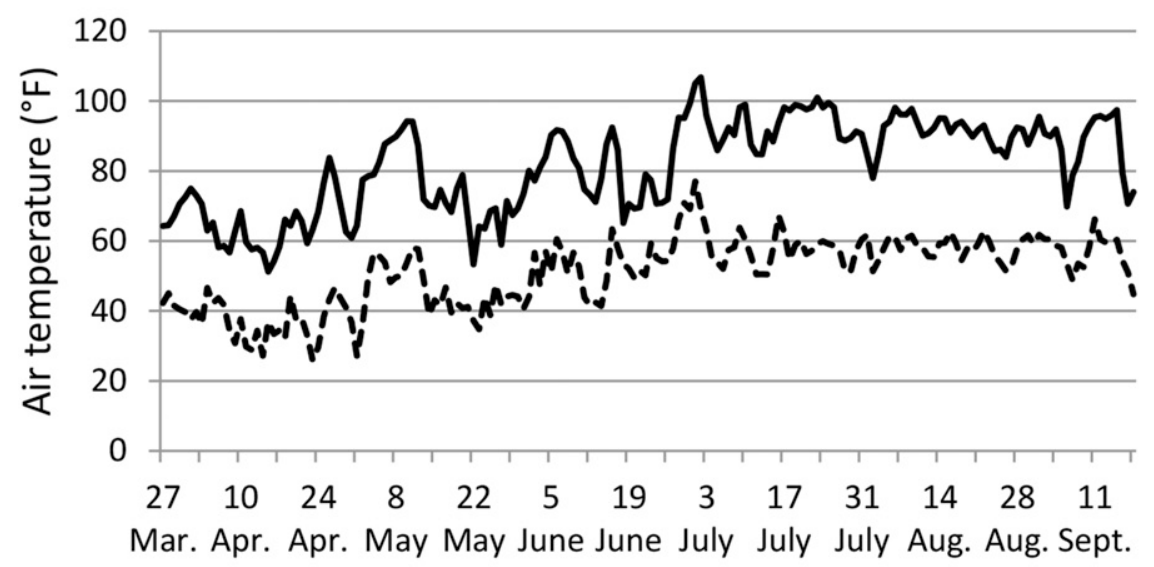

Date - 2013

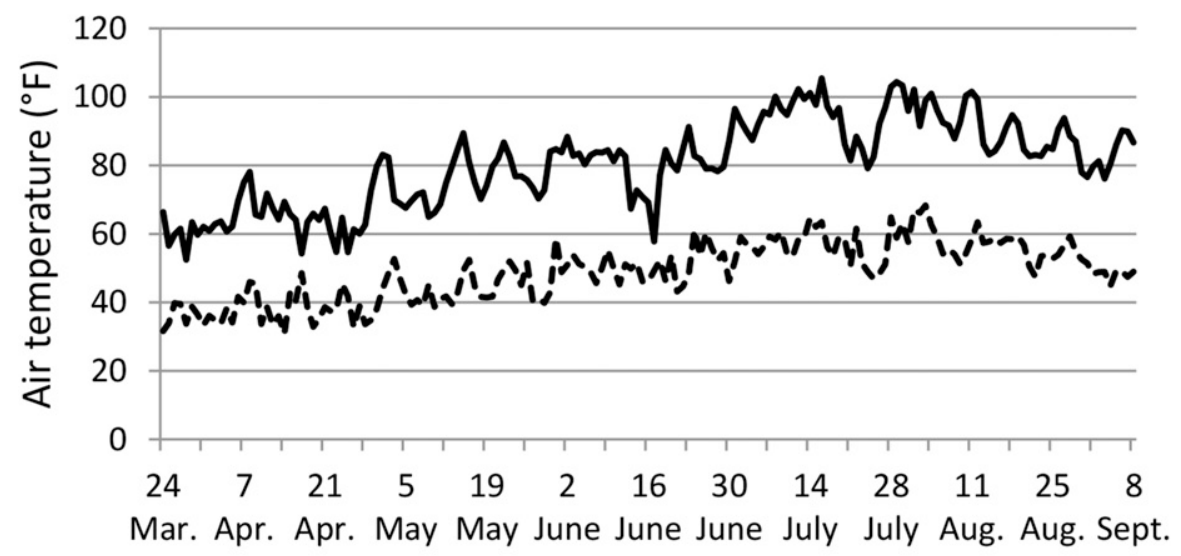

Date - 2014

\section{-Maximum - - Minimum}

Fig. 2. Daily maximum and minimum temperatures recorded in the period from planting to undercutting onions in the Washington State University Onion Cultivar Trials in 2012, 2013, and 2014. Temperatures were recorded at Washington Agricultural Weather Network stations located nearest the trial each year; $\left({ }^{\circ} \mathrm{F}-32\right) \div 1.8={ }^{\circ} \mathrm{C}$. 
Table 5. The average number of bolters for each onion cultivar evaluated in the Washington State University Onion Cultivar Trial in 2012 and 2014. Cultivars are presented in order from the most to the fewest bolters.

\begin{tabular}{|c|c|c|c|}
\hline Cultivar $^{\mathrm{z}}$ & $\mathrm{Yr}$ & Seed company ${ }^{\mathrm{y}}$ & Bolters (no./plot) \\
\hline Cometa $(\mathrm{W})$ & 2012 & Nunhems & $15.5 \mathrm{a}^{\mathrm{w}}$ \\
\hline Advantage & 2012 & Crookham & $15.0 \mathrm{ab}$ \\
\hline Granero & 2012 & Nunhems & $15.0 \mathrm{ab}$ \\
\hline TTA-747 & 2012 & American Takii & $15.0 \mathrm{ab}$ \\
\hline Bello Blanco $(W)$ & 2012 & Sakata & $14.7 \mathrm{abc}$ \\
\hline Maverick & 2012,2014 & Hazera & $14.0 \mathrm{abc}$ \\
\hline Pandero & 2012,2014 & Nunhems & $11.5 \mathrm{a}-\mathrm{d}$ \\
\hline Joaquin & 2012,2014 & Nunhems & $11.3 \mathrm{a}-\mathrm{e}$ \\
\hline SV4058NV (W) & 2012,2014 & Nunhems & $10.8 \mathrm{a}-\mathrm{f}$ \\
\hline Scout & 2012,2014 & Crookham & $10.7 \mathrm{a}-\mathrm{g}$ \\
\hline Ventura & 2012 & Hazera & $10.7 \mathrm{a}-\mathrm{g}$ \\
\hline Belmar & 2012,2014 & Seminis & $9.7 \mathrm{a}-\mathrm{h}$ \\
\hline Sedona & 2012 & Bejo & $9.7 \mathrm{a}-\mathrm{h}$ \\
\hline Swale & 2012,2014 & Seminis & $9.7 \mathrm{a}-\mathrm{h}$ \\
\hline Montero & 2012,2014 & Nunhems & $9.5 \mathrm{a}-\mathrm{h}$ \\
\hline Anillo & 2012,2014 & Nunhems & $9.3 \mathrm{a}-\mathrm{h}$ \\
\hline SV6672NW & 2014 & Seminis & $9.3 \mathrm{a}-\mathrm{h}$ \\
\hline Pontiac & 2012,2014 & Crookham & $8.2 \mathrm{~b}-\mathrm{i}$ \\
\hline Utrero & 2014 & Nunhems & $7.7 \mathrm{c}-\mathrm{j}$ \\
\hline XP07716000 & 2014 & Seminis & $6.3 \mathrm{~d}-\mathrm{k}$ \\
\hline Scorpion & 2012,2014 & Crookham & $5.8 \mathrm{~d}-\mathrm{k}$ \\
\hline Campero & 2014 & Nunhems & $5.7 \mathrm{~d}-\mathrm{k}$ \\
\hline Crockett & 2012,2014 & Bejo & $5.0 \mathrm{~d}-\mathrm{k}$ \\
\hline Gunnison & 2012 & Bejo & $5.0 \mathrm{~d}-\mathrm{k}$ \\
\hline Delgado & 2012,2014 & Вејо & $4.8 \mathrm{~d}-\mathrm{k}$ \\
\hline Arcero & 2012,2014 & Nunhems & $4.5 \mathrm{~d}-\mathrm{k}$ \\
\hline Brundage (W) & 2014 & Crookham & $4.3 \mathrm{e}-\mathrm{k}$ \\
\hline Calibra & 2012,2014 & Bejo & $4.3 \mathrm{e}-\mathrm{k}$ \\
\hline Morpheus & 2012,2014 & Crookham & $4.0 \mathrm{f}-\mathrm{k}$ \\
\hline Esteem & 2012,2014 & Crookham & $3.8 \mathrm{f}-\mathrm{k}$ \\
\hline Vaquero & 2012,2014 & Nunhems & $3.8 \mathrm{f}-\mathrm{k}$ \\
\hline Red Bull (R) & 2012,2014 & Bejo & $3.7 \mathrm{~g}-\mathrm{k}$ \\
\hline SV4643NT (R) & 2012,2014 & Seminis & $3.7 \mathrm{~g}-\mathrm{k}$ \\
\hline Valero & 2014 & Nunhems & $3.7 \mathrm{~g}-\mathrm{k}$ \\
\hline Elbrus & 2012,2014 & Seminis & $3.2 \mathrm{~h}-\mathrm{k}$ \\
\hline Talon & 2012,2014 & Bejo & $3.0 \mathrm{~h}-\mathrm{k}$ \\
\hline Legend & 2012,2014 & Bejo & $1.5 \mathrm{ijk}$ \\
\hline Redwing & 2012,2014 & Bejo & $1.5 \mathrm{ijk}$ \\
\hline Centerstone & 2012,2014 & American Takii & $1.3 \mathrm{ijk}$ \\
\hline Countach (R) & 2014 & Nunhems & $1.3 \mathrm{ijk}$ \\
\hline Cruiser & 2012,2014 & Hazera & $1.3 \mathrm{ijk}$ \\
\hline Tamara & 2012 & Bejo & $1.3 \mathrm{ijk}$ \\
\hline Ovation & 2012,2014 & Sakata & $1.2 \mathrm{ijk}$ \\
\hline Purple Haze & 2014 & Crookham & $1.0 \mathrm{jk}$ \\
\hline NUN7202ON & 2014 & Nunhems & $1.0 \mathrm{jk}$ \\
\hline Trigger & 2012,2014 & Crookham & $1.0 \mathrm{jk}$ \\
\hline Marenge (R) & 2012,2014 & Nunhems & $0.7 \mathrm{jk}$ \\
\hline SV6646NW & 2014 & Seminis & $0.7 \mathrm{jk}$ \\
\hline Milestone & 2012,2014 & American Takii & $0.3 \mathrm{k}$ \\
\hline NUN8003ON (W) & 2014 & Nunhems & $0.3 \mathrm{k}$ \\
\hline Ruby Ring (R) & 2012 & American Takii & $0.3 \mathrm{k}$ \\
\hline Trailblazer & 2012,2014 & American Takii & $0.2 \mathrm{k}$ \\
\hline Highlander & 2014 & American Takii & $0.0 \mathrm{k}$ \\
\hline Trekker & 2012,2014 & American Takii & $0.0 \mathrm{k}$ \\
\hline Grand mean & & & 5.7 \\
\hline ANOVA & & & \\
\hline
\end{tabular}

(Continued on next page) significant cultivar effect on the percentage of culls when averaged across years (Table 2). However, there were significant year and cultivar effects on the numbers of bolted onions in each plot (Table 2). In fact, most of the culls in the 2012 and 2014 trials were onions that had bolted. Bolters were not assessed in 2013 , because only a few plants bolted, but the other 2 years had more bolted onions than has been typical for these onion cultivar trials. The 2012 trial averaged more bolted onions (7.9 per plot) than the 2014 trial (3.5 per plot) (Table 2). Bolting in onions can occur when plants are exposed to cool temperatures (46 to $54^{\circ} \mathrm{F}$ is optimal) for a period after they have reached a critical size, generally after they have initiated seven or more leaves (Brewster, 2008). In the Columbia Basin, spring-seeded onions usually reach the seven-leaf stage in June. A comparison of daily minimum air temperatures in June of each year probably explains the differences observed for bolting each year. Daily minimum air temperatures in June tended to be cooler in 2012 compared with 2013 and 2014 (Fig. 2). The monthly average minimum temperature for June was $48{ }^{\circ} \mathrm{F}$ in $2012,54{ }^{\circ} \mathrm{F}$ in 2013 , and $51{ }^{\circ} \mathrm{F}$ in 2014.

There was no year $\times$ cultivar interaction for the number of bolters in 2012 and 2014, so the results from both years were combined and compared for each cultivar. The critical size for onion plants to become receptive to a cold stimulus and the critical temperature varies depending on the cultivar (Brewster, 2008), so it is not surprising that there were cultivar differences. The average number of bolters for cultivars ranged from 0.0 to 15.5 per plot, and averaged 5.7 per plot (Table 5). Cometa, Advantage, Granero, and TTA-747 had the largest numbers of bolted onions, but all of these cultivars were entered in the 2012 trial and not in the 2014 trial that averaged fewer bolted onions per plot. The cultivars with the most bolters that were evaluated both years were Maverick, Pandero, Joaquin, SV4058NV, Scout, and Ventura. The cultivars with the fewest bolted onions across years were Trekker, Highlander, Trailblazer, Ruby Ring, NUN8003ON, and Milestone; all but one of these cultivars was entered by the seed company, American Takii (Salinas, CA). In fact, with the exception of 'TTA-747', all of the cultivars 
Table 5. (Continued) The average number of bolters for each onion cultivar evaluated in the Washington State University Onion Cultivar Trial in 2012 and 2014. Cultivars are presented in order from the most to the fewest bolters.

\begin{tabular}{|c|c|c|c|}
\hline Cultivar $^{\mathrm{z}}$ & Yr & Seed company & Bolters (no./plot) ${ }^{x}$ \\
\hline Year & & & 0.0001 \\
\hline Cultivar & & & 0.0001 \\
\hline Year $\times$ cultivar & & & NS \\
\hline
\end{tabular}

${ }^{\mathrm{z}}(\mathrm{R})=$ red cultivar, $(\mathrm{W})=$ white cultivar; cultivars that are not red or white are yellow.

yAmerican Takii (Salinas, CA), Bejo = Bejo Seeds (Oceano, CA), Crookham = Crookham Co. (Caldwell, ID), Hazera $=$ Hazera Seeds $($ Tuscon, AZ), Nunhems $=$ Nunhems USA (Brooks, OR), Sakata = Sakata Seed America $($ Messilla, NM), Seminis = Seminis Vegetable Seeds $($ Parma, ID).

${ }^{x}$ Plot $=$ two double rows of onions $\times 30 \mathrm{ft}(9.1 \mathrm{~m})$ long.

"Values followed by different letters within a column are significantly different using Fisher's least significant difference test at the $1 \%$ level; NS $=$ not significant at $P \leq 0.01$.

belonging to American Takii demonstrated excellent resistance to bolting under the conditions experienced in these trials in 2012 and 2014.

There were significant year effects for most of the characteristics evaluated during the poststorage evaluations, including uniformity of shape, bulb firmness, the percentage of sprouts, and the percentage of functional single centers (Table 6). The rating for shape was higher, suggesting that bulbs were more uniformly shaped, in 2014 (3.8) compared with the other years ( 3.5 for both 2012 and $2013)$. The average firmness rating was higher, suggesting that bulbs were firmer, in 2014 (3.7) and 2013 (3.6) than in 2012 (3.0). However, these are subjective ratings that depend on the interpretation of evaluators, and the evaluators were different groups of people each year, which makes it difficult to compare years. The onion bulbs sprouted more in 2014, averaging $11.8 \%$ sprouted bulbs, compared with 2012 when $2.3 \%$ of the bulbs sprouted, and 2013 when only $0.1 \%$ of bulbs sprouted. Many things could account for these differences, but no single factor stands out as the cause. The average percentage of functionally singlecentered bulbs was largest in 2012 (60.1\%) and smallest in 2013 (54.8\%), though a difference of $5.3 \%$ does not seem very large. There was no significant year effect on skin retention (Table 6).

Since there were no cultivar $x$ year interactions for uniformity of bulb shape, skin retention, and bulb firmness ratings, or for the percentage of functionally single-centered bulbs, the results from the 3 years were combined for each cultivar (Table 7). The shape ratings differed between cultivars, but were unaffected by the year (Table 7). The average shape rating for all cultivars was 3.6 (Table 7). The cultivars with the most uniform bulbs were Utrero, Trekker, NUN7202ON, and Tamara, which were given an average rating of 4.4 to 4.3 for shape. This rating was significantly higher than the average shape ratings given to 22 other cultivars. The cultivars with the most variable shape were Pontiac and Highlander both with an average rating of 2.7, followed by XP0771600 with an average rating of 2.8 . The ratings for uniformity of shape do not indicate anything about the actual shape of the onion bulbs (i.e., whether they tend to be round or globe shaped, and blocky, flattened, or tall), because preference in shape is a subjective value that is not easily rated.

Skin retention ratings differed for cultivars, but were unaffected by the year (Table 7). The average rating for skin retention was 3.6 (Table 7). The cultivars with the highest average skin retention rating of 4.8 were Crockett, Legend, and Utrero. This rating was significantly higher than the skin retention ratings given to 37 other cultivars (Table 7). 'NUN7202ON', 'Granero', 'Tamara', and 'Valero' were also given high skin retention ratings of 4.5 or higher. The cultivar with the lowest skin retention rating was Highlander with a rating of 1.5 , followed by Ovation with a rating of 1.9 , and then Scout with a rating of 2.3 (Table 7). These cultivars had bulbs with incomplete skins (mostly bald) that would be deemed unmarketable for fresh sales. The red cultivars tended to have poor skin retention; five of the seven red cultivars in these trials were given lower than average ratings for skins (Table 7 ). Red Bull and Redwing were the two red cultivars with better than average skin retention ratings of 4.1 and 4.0 , respectively (Table 7 ).

The average rating for bulb firmness was 3.5 (Table 7). The cultivar that had the highest average rating for bulb firmness was Crockett with a rating of 4.8 , followed by Talon and Utrero both with an average rating of 4.6 , Legend with an average rating of

Table 6. Average ratings for bulb qualities including shape, skin retention, and firmness and the average percentages of bulbs with functional single centers, sprouts, and rots for onions evaluated in the Washington State University Onion Cultivar Trials in 2012, 2013, and 2014.

\begin{tabular}{|c|c|c|c|c|c|c|c|}
\hline$\underline{\mathbf{Y r}}$ & $\begin{array}{c}\text { Shape } \\
(1-5 \text { scale })^{z}\end{array}$ & $\begin{array}{c}\text { Skins } \\
(1-5 \text { scale })^{y}\end{array}$ & $\begin{array}{l}\text { Firmness } \\
(1-5 \text { scale })^{x}\end{array}$ & $\begin{array}{l}\text { Single or small centers } \\
(\%)^{\mathrm{w}}\end{array}$ & $\begin{array}{l}\text { Sprouts } \\
(\%)\end{array}$ & $\begin{array}{c}\text { Neck rot } \\
(\%)\end{array}$ & $\begin{array}{c}\text { Bacterial rot } \\
(\%)\end{array}$ \\
\hline 2012 & 3.5 & 3.6 & 3.0 & 60.1 & 2.3 & 1.7 & 1.1 \\
\hline 2014 & 3.8 & 3.5 & 3.7 & 57.8 & 11.8 & 1.3 & 4.9 \\
\hline \multicolumn{8}{|l|}{ ANOVA $^{v}$} \\
\hline Year & 0.0001 & NS & 0.0001 & 0.0002 & 0.0001 & NS & 0.0001 \\
\hline
\end{tabular}

${ }^{\mathrm{z}} 1=$ extremely variable shapes, 5 = highly uniform.

${ }^{y} 1=75 \%$ or more of the bulb is bald, $2=50 \%$ to $75 \%$ of the bulb is bald, $3=$ partial balding but more than $50 \%$ of the skin is present, $4=$ complete but some cracks in the skin, $5=$ complete and no cracks.

${ }^{\mathrm{x}} \mathrm{l}=$ soft, $5=$ very hard.

"Bulbs with single centers or small multiple centers $\leq 1$-inch in diameter; 1 inch $=2.54 \mathrm{~cm}$.

vAnalysis of variance for the effects of year, cultivar, and year $\times$ cultivar; NS $=$ not significant at $P \leq 0.01$. 
VARIETY TRIALS

Table 7. Ratings for bulb qualities including shape, skin retention, and firmness, and the percentages of bulbs with functional single centers for each cultivar evaluated in the Washington State University Onion Cultivar Trial over 3 years from 2012 to 2014. Cultivars are presented in order from the largest to the smallest total marketable yield.

\begin{tabular}{|c|c|c|c|c|c|}
\hline Cultivar $^{\mathrm{z}}$ & Yr & $\begin{array}{c}\text { Shape } \\
(1-5 \text { scale })^{y}\end{array}$ & $\begin{array}{c}\text { Skins } \\
(1-5 \text { scale })^{x}\end{array}$ & $\begin{array}{c}\text { Firmness } \\
(\mathbf{1 - 5} \text { scale })^{\mathrm{w}}\end{array}$ & $\begin{array}{c}\text { Single or small centers } \\
(\%)^{\mathrm{v}}\end{array}$ \\
\hline TTA-747 & 2012,2013 & $3.7 \mathrm{a}-\mathrm{i}^{\mathrm{u}}$ & $4.0 \mathrm{a}-\mathrm{g}$ & $3.0 \mathrm{j}-\mathrm{O}$ & $59.4 \mathrm{i}-\mathrm{n}$ \\
\hline Scout & All & $3.1 \mathrm{~h}-\mathrm{k}$ & $2.3 \mathrm{lmn}$ & $2.81-\mathrm{p}$ & $61.0 \mathrm{~h}-\mathrm{m}$ \\
\hline SV6672NW & 2013,2014 & $3.8 \mathrm{a}-\mathrm{h}$ & $3.4 \mathrm{f}-\mathrm{j}$ & $3.3 \mathrm{f}-\mathrm{n}$ & 73.7 b-i \\
\hline Montero & All & $3.4 \mathrm{c}-\mathrm{k}$ & $3.2 \mathrm{~g}-1$ & $3.0 \mathrm{j}-\mathrm{O}$ & $70.7 \mathrm{c}-\mathrm{k}$ \\
\hline XP07716000 & 2013,2014 & $2.8 \mathrm{j}-\mathrm{k}$ & $2.7 \mathrm{j}-\mathrm{m}$ & $2.8 \mathrm{k}-\mathrm{p}$ & $76.5 \mathrm{a}-\mathrm{h}$ \\
\hline Vaquero & All & $3.7 \mathrm{a}-\mathrm{i}$ & $3.4 \mathrm{e}-\mathrm{j}$ & $3.3 \mathrm{~g}-\mathrm{O}$ & $71.7 \mathrm{c}-\mathrm{j}$ \\
\hline Morpheus & All & $3.7 \mathrm{a}-\mathrm{i}$ & $3.0 \mathrm{i}-\mathrm{j}$ & $2.8 \mathrm{j}-\mathrm{p}$ & $78.6 \mathrm{a}-\mathrm{g}$ \\
\hline Advantage & 2012,2013 & $3.3 \mathrm{e}-\mathrm{k}$ & $3.0 \mathrm{i}-1$ & $3.0 \mathrm{j}-\mathrm{O}$ & $70.0 \mathrm{c}-\mathrm{k}$ \\
\hline Arcero & All & $3.7 \mathrm{a}-\mathrm{i}$ & $3.7 c-i$ & $3.4 \mathrm{e}-\mathrm{m}$ & $89.7 \mathrm{ab}$ \\
\hline Cometa $(\mathrm{W})$ & All & $3.7 \mathrm{a}-\mathrm{i}$ & $3.3 \mathrm{f}-\mathrm{k}$ & $2.9 \mathrm{j}-\mathrm{p}$ & $81.3 \mathrm{a}-\mathrm{e}$ \\
\hline Swale & All & $3.7 \mathrm{a}-\mathrm{i}$ & $3.5 \mathrm{~d}-\mathrm{j}$ & $3.4 \mathrm{e}-\mathrm{m}$ & $69.9 \mathrm{~d}-\mathrm{k}$ \\
\hline Joaquin & All & $3.8 \mathrm{a}-\mathrm{i}$ & $4.3 \mathrm{a}-\mathrm{d}$ & $3.9 \mathrm{~b}-\mathrm{h}$ & $89.0 \mathrm{ab}$ \\
\hline Granero & 2012,2013 & $4.0 \mathrm{a}-\mathrm{f}$ & $4.5 \mathrm{abc}$ & $4.2 \mathrm{a}-\mathrm{e}$ & $77.5 \mathrm{a}-\mathrm{h}$ \\
\hline Elbrus & All & $3.8 \mathrm{a}-\mathrm{i}$ & $3.8 \mathrm{~b}-\mathrm{i}$ & $3.6 \mathrm{~d}-1$ & $38.5 \mathrm{p}-\mathrm{v}$ \\
\hline Campero & 2013,2014 & $3.8 \mathrm{a}-\mathrm{h}$ & $4.1 \mathrm{a}-\mathrm{f}$ & $4.0 \mathrm{a}-\mathrm{g}$ & $49.7 \mathrm{l}-\mathrm{r}$ \\
\hline Anillo & All & $3.6 \mathrm{~b}-\mathrm{j}$ & $3.7 \mathrm{c}-\mathrm{i}$ & $3.1 \mathrm{i}-\mathrm{O}$ & $77.6 \mathrm{a}-\mathrm{h}$ \\
\hline Sedona & 2013,2014 & $3.3 \mathrm{e}-\mathrm{k}$ & $3.8 c-i$ & $3.7 \mathrm{c}-\mathrm{j}$ & $48.6 \mathrm{~m}-\mathrm{s}$ \\
\hline Belmar & All & $3.7 \mathrm{a}-\mathrm{i}$ & $3.4 \mathrm{e}-\mathrm{j}$ & $3.2 \mathrm{~h}-\mathrm{O}$ & $70.4 \mathrm{c}-\mathrm{k}$ \\
\hline Pandero & All & $3.8 \mathrm{a}-\mathrm{h}$ & $4.4 \mathrm{abc}$ & $3.9 \mathrm{~b}-\mathrm{i}$ & $65.3 \mathrm{e}-\mathrm{m}$ \\
\hline Calibra & All & $3.8 \mathrm{a}-\mathrm{i}$ & $3.8 c-i$ & $3.6 \mathrm{~d}-1$ & $21.0 \mathrm{wx}$ \\
\hline Delgado & All & $4.1 \mathrm{a}-\mathrm{e}$ & $4.3 \mathrm{a}-\mathrm{e}$ & $4.3 \mathrm{a}-\mathrm{d}$ & $29.7 \mathrm{t}-\mathrm{x}$ \\
\hline Esteem & All & $3.5 c-j$ & $3.6 \mathrm{~d}-\mathrm{i}$ & $3.7 c-j$ & $78.3 \mathrm{a}-\mathrm{g}$ \\
\hline Utrero & 2013,2014 & $4.4 \mathrm{a}$ & $4.8 \mathrm{a}$ & $4.6 \mathrm{ab}$ & $86.9 \mathrm{abc}$ \\
\hline Cruiser & All & $3.7 \mathrm{a}-\mathrm{i}$ & $3.7 c-i$ & $3.4 \mathrm{e}-\mathrm{m}$ & $62.0 \mathrm{~g}-\mathrm{m}$ \\
\hline Centerstone & All & $3.3 \mathrm{f}-\mathrm{k}$ & $3.0 \mathrm{i}-1$ & $3.4 \mathrm{e}-\mathrm{m}$ & $34.5 \mathrm{r}-\mathrm{x}$ \\
\hline Gunnison & 2012,2013 & $4.2 \mathrm{a}-\mathrm{d}$ & $4.0 \mathrm{a}-\mathrm{g}$ & $4.3 \mathrm{a}-\mathrm{d}$ & $55.5 \mathrm{j}-\mathrm{O}$ \\
\hline NUN7202ON & 2013,2014 & $4.3 \mathrm{ab}$ & $4.7 \mathrm{ab}$ & $4.1 \mathrm{a}-\mathrm{f}$ & $92.6 \mathrm{a}$ \\
\hline Talon & All & $4.2 \mathrm{abc}$ & $4.1 \mathrm{a}-\mathrm{f}$ & $4.6 \mathrm{ab}$ & $42.8 \mathrm{n}-\mathrm{t}$ \\
\hline Tamara & 2012,2013 & $4.3 \mathrm{ab}$ & $4.5 \mathrm{abc}$ & $4.3 \mathrm{a}-\mathrm{d}$ & $34.8 \mathrm{r}-\mathrm{x}$ \\
\hline Highlander & 2013,2014 & $2.7 \mathrm{k}$ & $1.5 \mathrm{n}$ & $2.2 \mathrm{p}$ & $2.8 \mathrm{y}$ \\
\hline Trekker & All & $4.4 \mathrm{a}$ & $3.9 \mathrm{~b}-\mathrm{h}$ & $3.9 \mathrm{~b}-\mathrm{i}$ & $19.7 x$ \\
\hline Red Bull (R) & 2013,2014 & $3.4 \mathrm{~d}-\mathrm{k}$ & $4.1 \mathrm{a}-\mathrm{f}$ & $3.1 \mathrm{i}-\mathrm{O}$ & $34.6 \mathrm{r}-\mathrm{x}$ \\
\hline Trailblazer & All & $3.9 \mathrm{a}-\mathrm{g}$ & $3.2 \mathrm{~g}-1$ & $3.9 \mathrm{~b}-\mathrm{h}$ & $24.7 \mathrm{u}-\mathrm{x}$ \\
\hline Milestone & All & $3.9 \mathrm{a}-\mathrm{g}$ & $3.8 \mathrm{c}-\mathrm{i}$ & $3.1 \mathrm{i}-\mathrm{O}$ & $34.8 \mathrm{r}-\mathrm{x}$ \\
\hline Trigger & 2012,2014 & $3.3 \mathrm{e}-\mathrm{k}$ & $4.1 \mathrm{a}-\mathrm{f}$ & $3.4 \mathrm{e}-\mathrm{m}$ & $79.2 \mathrm{a}-\mathrm{f}$ \\
\hline Scorpion & All & $3.2 \mathrm{f}-\mathrm{k}$ & $3.5 \mathrm{~d}-\mathrm{j}$ & $3.9 \mathrm{~b}-\mathrm{i}$ & $66.9 \mathrm{~d}-\mathrm{k}$ \\
\hline Ruby Ring (R) & 2012,2013 & $3.2 \mathrm{~g}-\mathrm{k}$ & $3.2 \mathrm{~g}-1$ & $2.5 \mathrm{op}$ & $55.0 \mathrm{j}-\mathrm{p}$ \\
\hline Brundage (W) & 2013,2014 & $3.5 \mathrm{c}-\mathrm{j}$ & $3.2 \mathrm{~g}-1$ & $2.8 \mathrm{k}-\mathrm{p}$ & $81.0 \mathrm{a}-\mathrm{e}$ \\
\hline Pontiac & All & $2.7 \mathrm{k}$ & $3.4 \mathrm{e}-\mathrm{j}$ & $3.6 \mathrm{~d}-\mathrm{k}$ & $76.9 \mathrm{a}-\mathrm{h}$ \\
\hline Marenge (R) & All & $3.3 \mathrm{e}-\mathrm{k}$ & $2.6 \mathrm{klm}$ & $2.7 \mathrm{~m}-\mathrm{p}$ & $42.4 \mathrm{n}-\mathrm{t}$ \\
\hline Purple Haze (R) & 2013,2014 & $3.3 \mathrm{e}-\mathrm{k}$ & $3.0 \mathrm{i}-1$ & $3.1 \mathrm{j}-\mathrm{O}$ & $63.9 \mathrm{f}-\mathrm{m}$ \\
\hline Countach $(\mathrm{R})$ & 2013,2014 & $3.2 \mathrm{~g}-\mathrm{k}$ & $2.7 \mathrm{j}-\mathrm{m}$ & $3.2 \mathrm{~h}-\mathrm{O}$ & $21.8 \mathrm{vwx}$ \\
\hline Grand mean & & 3.6 & 3.6 & 3.5 & 57.8 \\
\hline
\end{tabular}


Table 7. (Continued) Ratings for bulb qualities including shape, skin retention, and firmness, and the percentages of bulbs with functional single centers for each cultivar evaluated in the Washington State University Onion Cultivar Trial over 3 years from 2012 to 2014. Cultivars are presented in order from the largest to the smallest total marketable yield.

\begin{tabular}{|c|c|c|c|c|c|}
\hline Cultivar $^{\mathrm{z}}$ & Yr & $\begin{array}{c}\text { Shape } \\
(1-5 \text { scale })^{y}\end{array}$ & $\begin{array}{c}\text { Skins } \\
(1-5 \text { scale })^{x}\end{array}$ & $\begin{array}{c}\text { Firmness } \\
(1-5 \text { scale })^{\mathrm{w}}\end{array}$ & $\begin{array}{c}\text { Single or small centers } \\
(\%)^{\mathrm{v}}\end{array}$ \\
\hline \multicolumn{6}{|l|}{ ANOVA } \\
\hline Year & & 0.0001 & NS & 0.0001 & 0.0002 \\
\hline Cultivar & & 0.0001 & 0.0001 & 0.0001 & 0.0001 \\
\hline Year $\times$ cultivar & & NS & 0.0012 & NS & NS \\
\hline
\end{tabular}

ANOVA = analysis of variance.

${ }^{\mathrm{z}}(\mathrm{R})=$ red cultivar, $(\mathrm{W})=$ white cultivar; cultivars that are not red or white are yellow.

${ }^{\mathrm{y}} \mathrm{l}=$ extremely variable shapes, $5=$ highly uniform.

${ }^{\mathrm{x}} \mathrm{l}=75 \%$ or more of the bulb is bald, $2=50 \%$ to $75 \%$ of the bulb is bald, $3=$ partial balding but more than $50 \%$ of the skin is present, $4=$ complete but some cracks in the skin, $5=$ complete and no cracks.

w $1=$ soft, 5 = very hard.

"Bulbs with single centers or small multiple centers $\leq \mathrm{l}$-inch in diameter; $\mathrm{l}$ inch $=2.54 \mathrm{~cm}$.

"Values followed by different letters within a column are significantly different using Fisher's least significant difference test at the $1 \%$ level; Ns $=$ not significant at $P \leq 0.01$.

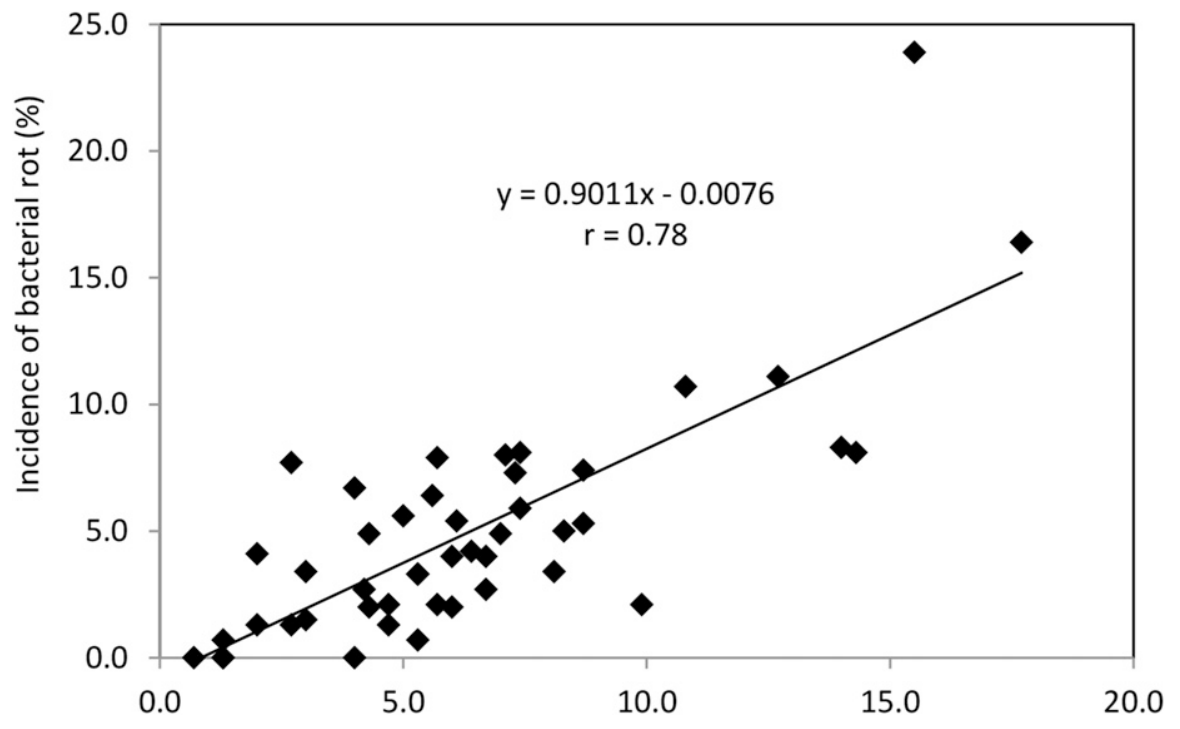

Fig. 3. Correlation between the percentage of onion bulbs with bacterial rot and the incidence of internal dry scale. Each data point represents a cultivar averaged across three replications. Only the 46 cultivars that were included in the Washington State University Onion Cultivar Trial in 2014 are included in this analysis.

4.4, and Gunnison and Tamara with an average rating of 4.3 (Table 7 ). These cultivars had average firmness ratings that were significantly higher than those of 33 other cultivars in the trials. Four of the five top-ranked cultivars for firmness were entered by Bejo Seeds (Oceano, CA), a seed company noted for developing onion cultivars that maintain their quality through several months of storage. 'Highlander' had the softest bulbs with an average rating of 2.2, followed by 'Ruby Ring' at 2.5, then 'Ovation' at 2.6, and 'Marenge' at 2.7 (Table 7). Six of the seven red cultivars, and five of the five white cultivars evaluated in these trials were given bulb firmness ratings that were lower than the average rating for all cultivars (Table 7). Redwing, which is another
Bejo Seeds cultivar, was the only red cultivar with a higher than average firmness rating (3.6) (Table 7).

Single centeredness is known to be a heritable trait in onion (Cramer, 2006; Shock et al., 2005; Wall et al., 1996), so it is not surprising that the ANOVA for this study reported a significant cultivar effect for the percentage of functionally single-centered onions in these trials (Tables 6 and 7). The percentage of bulbs with functional single centers was $57.8 \%$ when averaged across years and cultivars (Table 7 ). Based on the results of this study, most of the cultivars evaluated in these trials would not be a good choice for onion ring processing, since processors pay incentives to growers for delivering onions with at least $75 \%$ functionally single-centered bulbs (Shock et al.,
2005). Only 14 of the 54 cultivars met this benchmark. The cultivar with the largest average percentage of functionally single-centered bulbs was NUN7202ON at $92.6 \%$, followed by Arcero at $89.7 \%$ and Joaquin at $89.0 \%$, and then Utrero at $86.9 \%$ (Table 7). All of these cultivars were entered by Nunhems USA (Brooks, OR), which has been noted for developing onion cultivars that produce large proportions of single-centered bulbs. By contrast, 'Highlander' had the lowest average percentage of functionally single-centered bulbs at $2.8 \%$, followed by 'Trekker' at $19.7 \%$, and then 'Calibra' at $20.0 \%$. Shock et al. (2005) recommended that growers take care when choosing cultivars for singlecentered onion contracts, since only four of the 17 cultivars they evaluated over 3 years at the Malheur Experiment Station in Oregon consistently produced more than $74 \%$ functionally single-centered bulbs. The results of our trials, conducted more than a decade later, are similar and demonstrate that only a few of the long-day onion cultivars available today are a good choice for processing contracts that specify for functionally single-centered onions. However, it is notable that the average percentage of functionally single-centered bulbs in the WSU Onion Cultivar Trials has steadily increased over the years (Wohleb et al., 2012).

Storage rots affected only a small proportion of the bulbs each year. There was no year effect on the percentage of bulbs with neck rot, which averaged only $1.2 \%$ of the bulbs across years (Table 6). There was, however, a significant difference in the incidence of bacterial rot in 2014 (4.9\%), compared with 2012 (1.1\%) and 2013 $(0.7 \%)$ (Table 6$)$. The bacterial rot 
Table 8. The average percentage of bacterial rot for each onion cultivar evaluated in the Washington State University Onion Cultivar Trials in 2012, 2013, and 2014. Cultivars are presented in order from the largest to the smallest total marketable yield.

\begin{tabular}{|c|c|c|c|}
\hline \multirow[b]{2}{*}{ Cultivar $^{\mathrm{z}}$} & \multicolumn{3}{|c|}{ Bacterial rot (\%) } \\
\hline & 2012 & 2013 & 2014 \\
\hline TTA-747 & $0.0 \mathrm{~d}^{\mathrm{y}}$ & $0.0 \mathrm{~b}$ & \\
\hline Scout & $2.1 \mathrm{~cd}$ & $0.7 \mathrm{bc}$ & 7.3 \\
\hline SV6672NW & & $0.7 \mathrm{bc}$ & 1.3 \\
\hline Montero & $2.0 \mathrm{~cd}$ & $2.9 \mathrm{ab}$ & 3.3 \\
\hline XP07716000 & & $0.0 \mathrm{c}$ & 6.4 \\
\hline SV4058NV (W) & $2.0 \mathrm{~cd}$ & $4.0 \mathrm{a}$ & 6.7 \\
\hline Ovation & $5.6 \mathrm{bc}$ & $2.3 \mathrm{abc}$ & 16.4 \\
\hline Vaquero & $1.3 \mathrm{~d}$ & $0.0 \mathrm{c}$ & 7.4 \\
\hline Morpheus & $0.7 \mathrm{~d}$ & $2.0 \mathrm{abc}$ & 8.3 \\
\hline Advantage & $0.0 \mathrm{~d}$ & $2.7 \mathrm{abc}$ & \\
\hline Arcero & $0.7 \mathrm{~d}$ & $0.0 \mathrm{c}$ & 4.9 \\
\hline Cometa $(\mathrm{W})$ & $0.0 \mathrm{~d}$ & $2.7 \mathrm{abc}$ & 0.7 \\
\hline Swale & $0.0 \mathrm{~d}$ & $3.3 \mathrm{ab}$ & 5.4 \\
\hline SV6646NW & & $0.7 \mathrm{ab}$ & 5.6 \\
\hline Valero & & $0.0 \mathrm{c}$ & 0.0 \\
\hline Maverick & $0.7 \mathrm{~d}$ & $0.0 \mathrm{c}$ & 2.7 \\
\hline Joaquin & $0.0 \mathrm{~d}$ & $0.0 \mathrm{c}$ & 5.3 \\
\hline Granero & $0.7 \mathrm{~d}$ & $0.0 \mathrm{c}$ & \\
\hline Elbrus & $0.0 \mathrm{~d}$ & $0.0 \mathrm{c}$ & 4.1 \\
\hline Campero & & $2.0 \mathrm{abc}$ & 3.3 \\
\hline Anillo & $1.3 \mathrm{~d}$ & $0.0 \mathrm{c}$ & 2.7 \\
\hline Sedona & & $0.7 \mathrm{bc}$ & 3.4 \\
\hline Belmar & $0.0 \mathrm{~d}$ & $0.0 \mathrm{c}$ & 4.0 \\
\hline Pandero & $0.7 \mathrm{~d}$ & $0.0 \mathrm{c}$ & 1.3 \\
\hline Calibra & $2.0 \mathrm{~cd}$ & $0.7 \mathrm{bc}$ & 2.0 \\
\hline Delgado & $0.0 \mathrm{~d}$ & $0.0 \mathrm{c}$ & 0.0 \\
\hline Esteem & $0.7 \mathrm{~d}$ & $0.7 \mathrm{bc}$ & 2.1 \\
\hline Utrero & $0.0 \mathrm{c}$ & $0.0 \mathrm{~d}$ & 0.0 \\
\hline SV4643NT (R) & $6.7 \mathrm{ab}$ & $1.3 \mathrm{abc}$ & 1.5 \\
\hline Bello Blanco $(\mathrm{W})$ & $0.0 \mathrm{~d}$ & $1.3 \mathrm{abc}$ & \\
\hline NUN8003ON (W) & & $2.0 \mathrm{abc}$ & 7.7 \\
\hline Ventura & $0.0 \mathrm{~d}$ & $0.0 \mathrm{c}$ & \\
\hline Redwing (R) & $0.0 \mathrm{~d}$ & & 0.7 \\
\hline Legend & $0.7 \mathrm{~d}$ & $0.0 \mathrm{c}$ & 0.0 \\
\hline Crockett & $0.0 \mathrm{~d}$ & $0.7 \mathrm{bc}$ & 1.3 \\
\hline Cruiser & $0.7 \mathrm{~d}$ & $0.0 \mathrm{c}$ & 4.9 \\
\hline Centerstone & $0.7 \mathrm{~d}$ & $2.0 \mathrm{abc}$ & 6.0 \\
\hline Gunnison & $0.0 \mathrm{~d}$ & $0.0 \mathrm{c}$ & \\
\hline NUN7202ON & & $0.0 \mathrm{c}$ & 2.1 \\
\hline Talon & $1.3 \mathrm{~d}$ & $0.0 \mathrm{c}$ & 2.1 \\
\hline Tamara & $2.1 \mathrm{~cd}$ & $0.7 \mathrm{bc}$ & \\
\hline Highlander & & $1.3 \mathrm{abc}$ & 5.0 \\
\hline Trekker & $0.7 \mathrm{~d}$ & $0.0 \mathrm{c}$ & 2.0 \\
\hline Red Bull (R) & $0.0 \mathrm{~d}$ & $0.0 \mathrm{c}$ & 11.1 \\
\hline Trailblazer & $0.0 \mathrm{~d}$ & $0.0 \mathrm{c}$ & 4.0 \\
\hline Milestone & $0.7 \mathrm{~d}$ & $0.0 \mathrm{c}$ & 8.1 \\
\hline Trigger & $0.0 \mathrm{~d}$ & & 3.4 \\
\hline Scorpion & $0.7 \mathrm{~d}$ & $0.0 \mathrm{c}$ & 8.1 \\
\hline Ruby Ring (R) & $10.0 \mathrm{a}$ & $1.3 \mathrm{abc}$ & \\
\hline Brundage (W) & & $0.7 \mathrm{bc}$ & 8.0 \\
\hline Pontiac & $0.7 \mathrm{~d}$ & $0.7 \mathrm{bc}$ & 10.6 \\
\hline Marenge (R) & $1.3 \mathrm{~d}$ & $0.7 \mathrm{bc}$ & 23.9 \\
\hline Purple Haze (R) & & $0.0 \mathrm{c}$ & 4.2 \\
\hline
\end{tabular}

(Continued on next page) found in onion bulbs in 2014 was mostly associated with a condition known as internal dry scale (Fig. 3). Internal dry scale is a problem that occurs when one or more of the internal fleshy scales of the onion bulb collapse as a result of premature dieback of leaves during the growing season (du Toit et al., 2015). Internal dry scale was a widespread problem in the Columbia Basin in 2014, affecting onions grown by many different producers in the region. Many of the bulb samples received by university personnel in Fall and Winter 2014 had internal dry scales that were colonized by fungi (mainly Fusarium proliferatum), yeasts, and/or bacteria (du Toit et al., 2015). A regression analysis using mean results from the 46 onion cultivars evaluated in the 2014 trial was used to compare the incidence of bacterial rot in the trial with the percentage of bulbs that had internal dry scale (Fig. 3). The regression showed a strong positive correlation between incidence of bacterial rot and internal dry scale $(r=0.78)$. The reasons for the widespread incidence of internal dry scale and associated bulb rots in 2014 is not completely understood, but is thought to be related to heat stress and soil moisture management during periods of intense heat ( $\mathrm{du}$ Toit et al., 2015). The Columbia Basin experienced one of the warmest summers on record in 2014, especially during the mid-tolatter parts of the growing season.

There was no cultivar effect on the incidence of storage rots, but there were cultivar $\times$ year interactions affecting the incidence of bacterial rots (Table 6). There were significant differences between cultivars in 2012 and 2013, but not in 2014. The average incidence of bacterial rots for cultivars ranged from $0.0 \%$ to $10.0 \%$ in 2012 , and from $0.0 \%$ to $4.0 \%$ in 2013 (Table 8 ). There were five cultivars that consistently had greater than average incidences of bacterial rots in the years they were evaluated; Ruby Ring averaged $10.0 \%$ and $1.3 \%$ in 2012 and 2013 , respectively; Highlander averaged and $1.3 \%$ and $5.0 \%$ in 2013 and 2014 , respectively; NUN8003ON averaged $2.0 \%$ and $7.7 \%$ in 2013 and 2014 , respectively; Ovation averaged 5.6\%, 2.3\%, and $16.4 \%$ in 2012,2013 , and 2014 , respectively; and SV4058 NV averaged $2.0 \%, 4.0 \%$, and $6.7 \%$ in 2012,2013 , and 2014, respectively (Table 8 ). 
Table 8. (Continued) The average percentage of bacterial rot for each onion cultivar evaluated in the Washington State University Onion Cultivar Trials in 2012, 2013, and 2014. Cultivars are presented in order from the largest to the smallest total marketable yield.

\begin{tabular}{lccr}
\hline & \multicolumn{3}{c}{ Bacterial rot (\%) } \\
\cline { 2 - 4 } Cultivar $^{\mathrm{z}}$ & $\mathbf{2 0 1 2}$ & $\mathbf{2 0 1 3}$ & $\mathbf{2 0 1 4}$ \\
\hline Countach $(\mathrm{R})$ & & $0.0 \mathrm{c}$ & 7.9 \\
Grand mean & 1.1 & 0.7 & 4.9 \\
\hline
\end{tabular}

${ }^{\mathrm{z}}(\mathrm{R})=$ red cultivar, $(\mathrm{W})=$ white cultivar; cultivars that are not red or white are yellow.

'Values followed by different letters within a column are significantly different using Fisher's least significant difference test at the $1 \%$ level; NS $=$ not significant at $P \leq 0.01$.

\section{Conclusion}

Each of the new and advanced experimental cultivars evaluated in these trials have attributes that could make them a good fit for onion operations in the Columbia Basin. 'TTA747', 'SV6672NW', 'XP07716000', and 'SV6646NW' were some of the highest yielding onions in these trials. 'TTA-747' was recently released by American Takii and was given the name 'Grand Perfection'. It produced a higher proportion of colossal-sized bulbs compared with most of the cultivars in these trials, so it might be a good cultivar for growers who are looking to market large onions. 'SV6672NW' was given good ratings for uniformity of shape, near to average ratings for firmness and skin retention, and averaged $73.7 \%$ functional single centers. SV4058NV and NUN8003ON were among the top-yielding white cultivars and both were given better than average ratings for shape; they performed comparably to a popular standard white cultivar, Cometa. 'SV4643NT' was the top-yielding red onion, but like most other red cultivars, it did not get high ratings for uniformity of shape, skins, or firmness. Utrero, a yellow cultivar recently released by Nunhems USA had better than average yields and ratings for quality and storage attributes. This onion produced a high proportion of functional single centers (86.9\%). The advanced experimental cultivar NUN7202ON was not among the highest yielding onions, but it had some of the best ratings for shape, skins, and firmness, and the highest percentage of functional single centers in the trials $(92.6 \%)$. This cultivar was recently released by Nunhems USA and has been given the name Oloroso.

Clearly, there is no such thing as the perfect onion cultivar because there are many markets and end uses for dry bulb storage onions, each with specific needs. Nonetheless, onion growers, processing companies, packing sheds, and seed companies in the Columbia Basin can study these results to select cultivars that are most likely to suit their operations. These results demonstrate that each onion cultivar has specific attributes, one or more of which may be important for onion markets such as high total yields, large or small size, single centers, resistance to bolting, good skin retention, uniform shape, and low disease susceptibility. The data from the WSU Onion Cultivar Trials have benefitted the onion industry in the Columbia Basin for the last 30 years, allowing all stakeholders the opportunity to identify the onion cultivars that are most likely to fit their needs.

\section{Literature cited}

Brewster, J.L. 2008. Onions and other vegetable alliums. 2nd ed. CAB Intl., Wallingford, UK.

du Toit, L.J., T. Waters, and S. Reitz. 2015. Internal dry scale and associated bulb rots: Bane of the 2014 Pacific Northwest onion season. Onion World 31(4):4-7.

Cramer, C.S. 2006. Onion trait heritability and response from selection. J. Amer. Soc. Hort. Sci. 131:646-650.
Pelter, G.Q. and E.J. Sorensen. 2003. Crop profile for onions in Washington. Washington State Univ. Coop. Ext., U.S. Dept. Agr. MISC0373E.

Shock, C.C., E. Feibert, A. Riveira, and L.D. Saunders. 2004. Response of onion yield, grade, and financial return to plant population and irrigation system. HortScience 50:1312-1318.

Shock, C.C., E. Feibert, and L.D. Saunders. 2005. Single-centered and super colossal bulbs from yellow onion cultivars. HortTechnology 15:399-407.

Teviotdale, B.L., R.M. Davis, J.P. Guerard, and D.H. Harper. 1989. Effect of irrigation management on sour skin of onion. Plant Dis. 73:819-822.

U.S. Bureau of Reclamation. 2015. The Columbia Basin Project. 5 Oct. 2015. <http://www.usbr.gov/projects/ Project.jsp?proj_Name $=$ Columbia $\%$ 20Basin\%20Project>.

U.S. Department of Agriculture (USDA). 2014a. Agricultural Statistics 2014. Chapter IV: Statistics of vegetables and melons, p. 19. 5 Oct. 2015 . <http://www.nass. usda.gov/Publications/Ag_Statistics/ $2014 />$.

U.S. Department of Agriculture (USDA). 2014b. 2012 Census of Agriculture. Geographic Area Series, Volume 1, Part 47: Washington State and county data, p. 369-370. Table 29. Vegetables, potatoes, and melons harvested for sale: 2012 and 2007. 5 Oct. 2015. <http://www. agcensus.usda.gov/Publications/2012/ Full_Report/Volume_1,_Chapter_1_ State_Level/Washington/wavl.pdf $>$.

Wall, M.M., A. Mohammad, and J.N. Corgan. 1996. Heritability estimates and response to selection for the pungency and single center traits in onion. Euphytica 87:133-139.

Washington State University (WSU). 2015. Onion Cultivar Trial Results. 5 Oct. 2015. <http://ext100.wsu.edu/grantadams/agriculture/onion-cultivar-trialresults $/>$.

Wohleb, C.H., T.D. Waters, L.J. du Toit, and B.K. Schroeder. 2012. The Washington State University Onion Cultivar Trial: An important resource for Washington onion growers. Acta Hort. 969: 241246. 